\title{
ANÁLISE ECONÔMICA DA PRODUÇÃO DA BORRACHA NATURAL NO ESTADO DE SÃO PAULO
}

SILVIA TOLEDO ARRUDA

Orientador: Prof. Dr. EVARISTO MARZABAL NEVES

Dissertação apresentada à Escola Superior de Agricultura "Luiz de Queiroz"', da Universidade de São Paulo, para obtenção do título de Mestre em Agronomia, área de concentração em Economia Agrária.

PIR A C I C A B A

Estado de São Paulo - Brasil

Junho - 1986 
Aos Professores

RUY PINTO DA SILUA

da Faculdade de Ciências Econômicas de São Paulo da F.E.C. "Alvares Penteado"

e

RODOLFO HOFFMANN

da Escola Superior de Agricultura

"Luiz de queiroz USP 
i i i .

\section{AGRADECIMENTOS}

Ao Instituto de Economia Agrícola (IEA), da Coordenadoria Só cio-Econômica da Secretaria da Agricultura e Abastecimento do Estado de São Paulo; à Escola Superior de Agricultura "Luiz de Queiroz"., ESALQ/USP e à Empresa Brasileira de Pesquisa Agropecuária (EMBRAPA), pela oportunidade de realizar o curso;

Ao Professor Doutor Evaristo Marzabal Neves, pela amizade e orientação dispensada; aos demais Professores, pelas cri ticas e sugestões;

Ao Pesquisador Mário Cardoso, do Instituto Agronômico de Campinas (IAC) e aos Engentieiros Agrônomos Jayme Vasques Cortez e Carlos Eduardo de Siqueira Sampaio, da Coordena doria de Assistência Técnica Integral (CATI), pelas valiosas contribuições;

Aos Técnicos da Superintendência da Borracha (SUDHEVEA), do Ministério da Indūstria e Comércio, pelas informações fornecidas;

Ao José Fernando Simplício de 01 iveira, da CATI - DIRA do Litoral; ao Paulo de Souza Gonçalves, do Centro Nacional de Pesquisa da Seringueira e Dendé - EMBRAPA; ao Marcelo Nunes Ramos, aluno da ESALQ e estagiārio do IEA e ao Eng? Agro Ricardo Shirota, da Fundação de Estudos Agrärios Luiz de Queiroz (FEALQ), pela colaboração prestada;

Aos colegas e amigos do IEA: Afonso Negri Neto, Devancyr Appa recido Romão, Abel Ciro Minniti Igreja, Marina Brasil Rocha, Silvia R. Hellmeister, Lidia Hathue Ueno, Sonia Martins, Hiroshige Okawa, I kuyo Kiyuna, Maria Aurea Cassiano, Julio Cesar Gomes e Deborah Silva de 01 iveira, pelo apoio e colaboração durante a consecução desite trabalho; 
A Gabriela Menni Ferreri, do Serviço de Biblioteca e Documentação do IEA, pela elaboração da bibliografia;

A Ana de Assumpção Beltrame, ao Cleosival Bissi e Jorge Luiz Diorio pela correção do trabalho e serviço de datilografia;

Aos produtores rurais do Vale do Ribeira e de São José do Rio Preto, que gentilmente nos receberam;

finalizando, agradeço a Elba Lucy de Freitas Donald, cuja amizade foi imprescindível para a conclusão do curso e deste trabalho. 


\section{TNDICE}

Pàgina

RESUMO $\ldots \ldots \ldots \ldots \ldots \ldots \ldots \ldots \ldots \ldots \ldots \ldots \ldots \ldots \ldots \ldots \ldots \ldots$

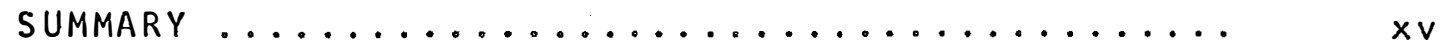

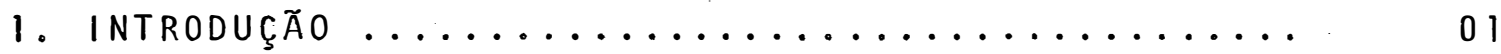

1.1. A Heveicultura no Estado de São Paulo ..... 01

1.2. Importância do Problema e objetivos........ 08

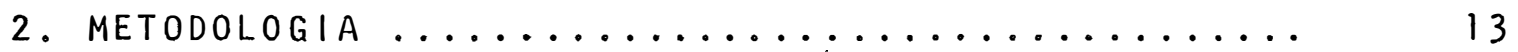

2.1. Fonte de Dados e Amostra............... 13

2.2. Método de Cálculo do Custo de Produção.... 16

2.3. Definição e Determinação dos Custos de Pro-

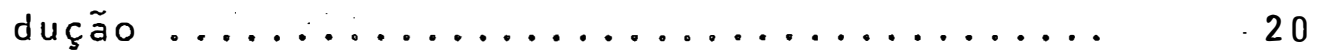

2.4. Produtividade dos Seringais Paulistas ..... 25

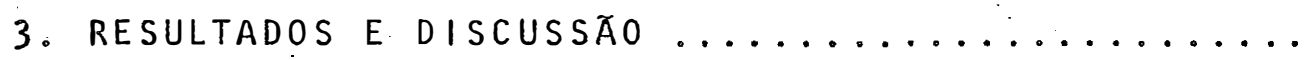

3.1. Custos Médios de Produção de Látex e de Borracha Seca para as Regiões do Vale do Ri

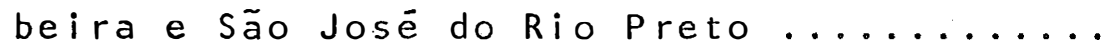

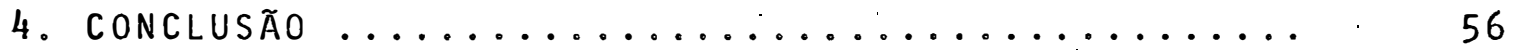

5. LITERATURA CITADA ......................... 61

APENDICE 1 - Aspectos da Heveicultura no Mundo e

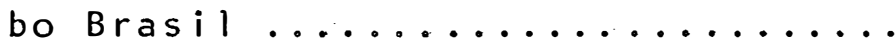

APENDICE 2 - Caracterização das Regiões e Siste-

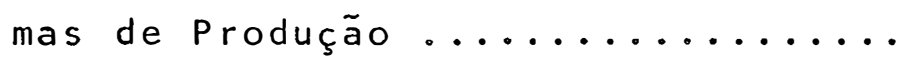


vi .

\section{LISTA DE TABELAS}

TABELA N

Pāgina

01 Distribuição Geogräfica dos Seringais Adul tos no Estado de São Paulo em 1981 .......

02

Distribuição das Classes de Aptidão Ecolōgica para a Cultura da Seringueira, por Região Administrativa, em Quilômetro Quadrado de Área, Estado de São Paulo .......

03 Cadastro Aproximado das Plantações de Seringueiras no Estado de São Paulo ........

04 Produtividade. Esperada, ml/Sangria, em Seringais Cultivados, para as Regiões do Vale do Ribeira e São José do Rio Preto, Es-

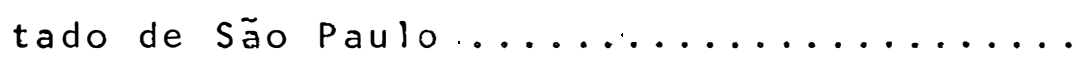

05 Produtividade Esperada, l lätex/ha/ano, em Seringais Cultivados, para as Regiões do Vale do Ribeira e São José do Rio Preto, E

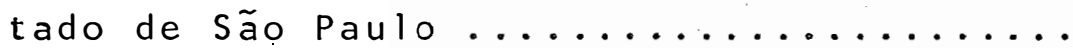

06 Produtividades Corrigidas, l látex/ha/ano, para Efeito de Cálculo dos Custos Unitärios, para Diferentes Taxas de Desconto, Re giões do Vale do Ribeira e São José do Rio Preto, Estado de São Paulo.............

07 Custo Médio Anualizado de Produção de Seringais, por Hectare, sob Diferentes. Taxas de Desconto, para Dois Sistemas de Produção, Vale do Ribeira, Estado de São Paulo. (em mil cruzeiros de Maio de 1985) ...... 
Custo Médio Anualizado- de Produção, por 1 itro de Látex, para Três Níveis de Produtividade por Hectare, em Dois Sistemas de Produção, Vale do Ribeira, Estado de São Paulo (em mil cruzeiros de Maio dé 1985).

09 Custo Médio Anualizado de Produção de Seringais, por Hectare, sob Diferentes Taxas de Desconto, para Três Sistemas de Produção, Região de São José do Rio Preto,. Estado de São Paulo (em mil cruzeiros de Maio

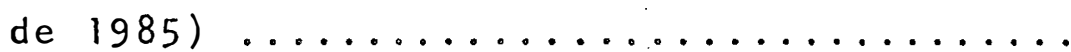

10 Custo Médio Anualizado de Produção, por 1 i tro de Látex, para Três Níveis de Produtividade por Hectare, em Três Sistemas de Produção, Região de São José do Rio Preto, Estado de São Paulo (em mil cruzeiros

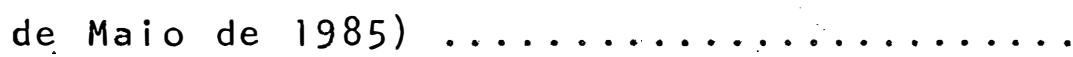

11 Custo Operacional Médio Anualizado de Produção, por Litro de Lātex, para Três Níveis de Produtividade por Hectare, em Dois Sistemas de Produção, Região do Vale do Ri beira, Estado de São Paulo (em mil cruzei-

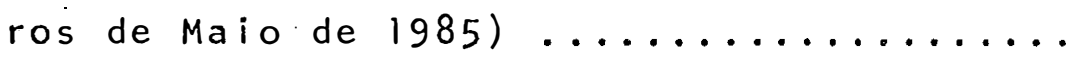

12 Custo Operacional Médio Anualizado de Produção, por Litro de Látex, para Três Níveis de Produtividade por Hectare, . em Três Sistemas de Produção, Região de São José do Rio Preto, Estado de São Paulo (em

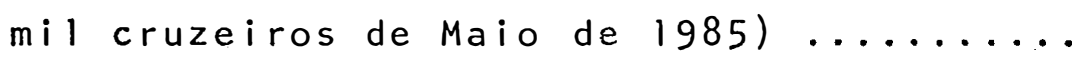


vi i i.

TABELA NO

Pägina

13 Produtividade, por ha/ano, de Borracha Seca. Obtida da Conversão Látex/Borracha Seca, em Três Níveis de Produtividade por Hectare, para ạs Regiões do Vale do Ribe ra e São José do Rio Preto, Estado de São

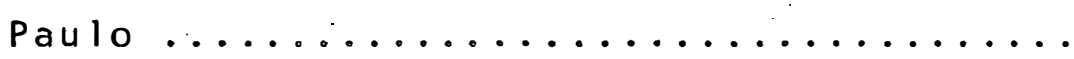

14 Custo Médio Anualizado de Produção, por quilo de Borracha Seca, para Três níveis de Produtividade por Hectare, em Dois Sistemas de Produção, Vale do Ribeira, Estado de São Paulo (em mil cruzeiros de Maio de 1985)

15 Custo Médio Anualizado de Produção, por quilo de Borracha Seca, para Três níveis de Produtividade, São José do Rio Preto, Estado de São Paulo (em mil cruzeiros de Maio de 1985)

16 Custo Operacional Médio Ảnualizado de Produ ção, por quilo de Borracha Seca, para Três Niveis de Produtividade Por Hectare, em Dois Sistemas de Produção, Vale do Ribei ra, Estado de São Paulo (em mil cruzei ros de Maio de 1985)

17 Custo Operacional Médio Anualizado de Produção, por quilo de Borracha Seca, para Três Níveis de Produtividade por Hectare, em Três Sistemas de Produção, São José do Rio Freto, Estado de São Paulo (em mil cru

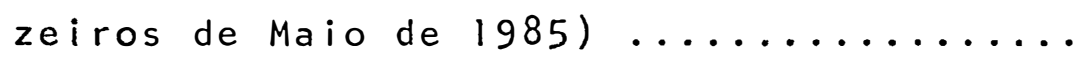


18 Custo Médio Anualizado de Produção, por qui lo de Borracha Seca, para Três Níveis de Produtividade por Hectare, em Três Sistemas de Produção; São José do Rio Preto, Es tado de São Paulo (em mil cruzeiros de Maio de 1985).

19 Evolução do Consumo Mundial de Borrachas no Período $1975 / 85$ (em 1.000 t/peso seco)

20 Evolução da Produção Mundial de Borrachas no Período $1975 / 85$ (em 1.000 t/peso seco)

21 Produção de Borrachas Naturais nos Principais Países e Brasil, 1972/81 (em 1.000 t/ peso seco)

22 Produção de Borracha na Amazōnia - 1827 /

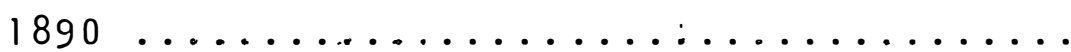

23 Evolução da Produção e do Consumo de. Borrachas Naturais no Brasil, Décadas de $50 /$ 60 e $61 / 70$ e no Período 1971/85 (em 1.000

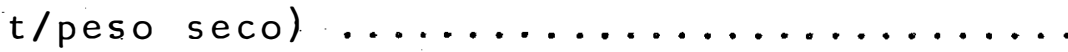

24 Evolução de Produção e do Consumo de Borrą chas Sintéticas no Brasil, Período 1963/

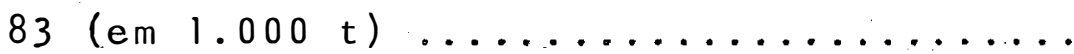

25 Produção Programada de Borracha Vegetal, Pe

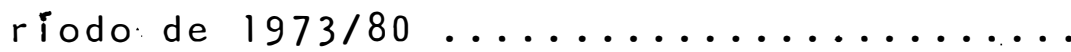


26 Coeficientes Técnicos e Preços de Fatores de Produção (Maio de 1985), para os Perío dos de Formação e Manutenção da Cultura da Seringueira, ha, 400 Plantas, Sistema de Produção:por Aquisição de Muda Enxertada e Plantio com Raiz Nua, Produtivi dade Média ha/ano: 2.000 l lätex, Vale do Ribeira, Estado de São Paulo ...........

27 Coeficientes Técnicos e Preços de Fatores de Produção (Maio de 1985), para os perío dos de Formação e Manutenção da Cultura da Seringueira, ha, 400 Plantas, Sistema de Produção de Formação de Muda Enxertada em Viveiros Prōprio, Produtividade Mé dia halano: 2.000 l de lätex, Vale do Ribeira, Estado de são Paulo............

28 Nümero Mëdio de Dias de Chuva, por Mẽs, em Duas Localidades da Região de São Josẻ do Rio Preto, Estado de São Paulo....

29 Coeficientes Técnicos e Preços dos Fatores de Produção (Maio de 1985), para os Períodos de Formação e Manutenção da Cultura da Seringueira, 1 ha, 400 . Plantas, Sistema de Produção por Formação de Porta-Enxerto e Enxertia de Campo, Produtivi dade Média ha/ano: 2.800 l lätex. Região de São José do Rio Preto, Estado de São

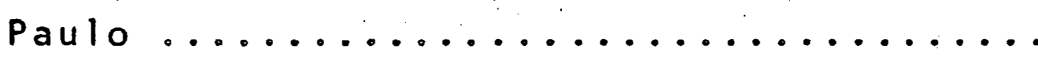


Coeficientes Técnicos e-Preços de Fatores de Produção (Maio de 1985), para os Perío dos de Formação e Manutenção da. Cultura da Seringueira,. I ha, 400 Plantas, Sistema de Produção por Formação de Mudas Enxertadas em Viveiro Prōprio, Produtividade Média ha/ano: 2.800 l de lätex, Região de São José do Rio Preto, Estado de

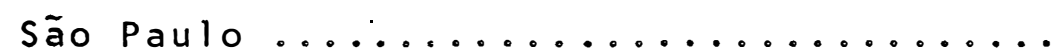

31. Coeficientes Técnicos e Preços de Fatores de Produção (Maio de 1985), para os Perío dos de Formação e Manutenção da Cultura da Seringueira, 1 ha, 400. Plantas, Sistema de Produção por Aquisição de Muda Enxertada, Produtividade Média ha/ano: 2.800 1 de lātex, Região de São José do Rio

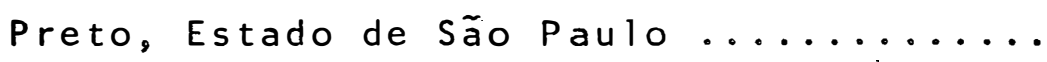




\title{
ANALISE ECONÔMICA DA PRODUৎAO DA BORRACHA NATURAL NO ESTADO DE SÃO PAULO
}

\author{
Autora: SILVIA TOLEDO ARRUDA \\ Orientador: Prof. Dr. EVARISTO MARZABAL NEVES
}

\section{RESUMO}

Em termos de borracha sintètica, o Brasil tornou-se praticamente auto-suficiente, além de contar com algum excedente exportável. Quanto à borracha natural o País encon tra-se, ainda hoje, com um deficit de produção, produzindo cerca de $60 \%$ de suas necessidades. Ressalta-se que o Governo Federal tem despendido vultuosos recursos em programas de incentivo ao aumento da produção da borracha natural.

- Estado de São Paulo, embora sem tradição na cultura da hevea, dispõe de áreas consideradas aptas e de con dições ecolögicas que permitem expandir o plantio da seringueira e, desse modo, contribuir para o aumento da produção. Contudo, a expansão da heveicultura traz consigo a necessidade de se incrementar os trabalhos de pesquisa, tanto na area agronômica como nạ ārea econômica.

o propósito deste estudo è analisar as estruturas de custo dos sistemas de produção em uso no Estado de São Paulo e proceder à determinação dos custos médios de pro- 
dução de borracha natural, por hectare e por unidade produzi da, considerando três níveis de produtividade por hectare/ano.

Utiliza-se a teoria de investimento em bens de produção, apropriando os custos para todo o horizonte temporal da cultura, estimado em vinte e sete anos.

Os cälculos são efetuados às taxas de desconto de $6 \%, 10 \%, 12 \%$ e $20 \%$ ao ano, dando-se ânfase à anālise dos resultados obtidos a taxa de $12 \%$ ao ano, como taxa mínima de atratividade ou custo alternativo do capital. os preços dos fatores de produção sao os que vigoraram no mês de maio de 1985; os resultados obtidos em cruzeiros são convertidos para dölares.

Como informação bāsica utiliza-se dados dos se ringais cultivados com capital prōprio em duas regiões do Estado de São Paulo: Vale do Ribeira e São José do Rio Preto.

os sistemas de produção analisados são: sistema - mudas adquiridas de viveiristas particulares; sistema 11 - mudas enxertadas em viveiro próprio; sistema 111 - formação de porta-enxerto em viveiro pröprio com enxertia no cam po. Para ambas as regiões considera-se três níveis de produtividade: mínimo, mëdio e mäximo.

Os custos médios por unidade produzida sao cal culados por litro de látex "in natura" e por quilo de borracha seca.

Para o Vale do Ribeira o custo médio mais baixo, de Cr\$3.940 ou US\$ 0,75 , e obtido para o sistema de produção 11 , ao nível mäximo de produtividade. 0 custo médio 
mais elevado, de Cr $\$ 7.180$ ou US\$1,37, é obtido para o sistema 1, ao nível mínimo de produtividade. Esse sistema e o mais comum entre os produtores do Vale do Ribeira.

Em São José do Rio Preto o menor custo médio, de Cr\$4.630 ou US\$ 0,89 è obtido no sistema de produção 111 , ao nível mảximo. Esse sistema é o mais comum nessa região, porēm, a produtividade conseguida pela maioria dos produtores corresponde ao nivel mínimo. Neste caso, o custo médio. é de Cr\$7.770 ou US\$1,49.

Em São José do Rio Preto os custos médios são mais altos do que no Vale do Ribeira. A razão é que na primeira região os custos fixos são mais elevados devido ao uso de maquinarias enquanto que na última região a cultura é conduzida manualmente.

Complementarmente, faz-se uma anālise comparativa com outra pesquisa que determinou custos de produção para a seringueira no Estado de São Paulo. 


\title{
ECONOMIC ANALYSIS OF NATURAL RUBBER PRODUCTION IN SÃO PAULO STATE
}

\author{
Author: SILVIA TOLEDO ARRUDA \\ Adviser: Prof. Dr. EVARISTO MARZABAL NEVES
}

\section{SUMMARY}

Brazil is not only self-sufficient producer of synthetical rubber but also an exceeding export. However, with respect to natural rubber, Brazil produces only $60 \%$ of its necessity. Worthwhile to point out that the Federal Government has spent massice resources through incentive programs to increase the natural rubber production.

São Paulo State does not have tradition in cropping Hevea, on the other hand its are considered with the best ecological condition to a possible expantion of the Hevea production. Also, there is lack of research works both in the agronomic and economic areas in são Paulo state. This study intend to add some knowledge in the rubber production cost.

The main objective of this study is to analyse the natural rubber production cost under different systems that has been in practice in two regions of São Paulo State: Vale do Ribeira and São José do Rio Preto. 
The investment theory in production goods is used with a length of planning horizon of 27 years, raining annual discount rates of $6 \%, 10 \%, 12 \%$ and $20 \%$, with three productivity levels (minimum, medium and maximum), and with the monetary values basis of may, 1985, either in cruzeiros or dollars. The average production cost in computed in liter of latex "in natura" and in kilo of dry rubber.

The production systems are: system I. young grafted tree from private nursery; system II: young tree grafting in farmer's nursery; system III: rootstock in farmer's nursery and from grafting in the yield.

In the Vale do Ribeira, the lowest average cost of. Cr\$3.940 or US\$ 0.75 is obtained in the case of the production system $1 \mathrm{l}$. The highest average cost of Cr $\$ 7.180$ or US\$ 1.37 is obtained in the case of the production system 1. The latter system is the most common among farmers in the Vale do Ribeira.

In São José do Rio Preto, the lowest average cost of Cr\$4.630 or US\$ 0.89 is obtained in the case of production system III. This is the most common production system in the region, however farmers have not been able to reach the productivity that researchers had been performing under experimental condition. In this sense the average cost of Cr\$7.770 or US\$ $1.49 \mathrm{might}$ be more appropriated to a great number of the farmers in this region.

São Josē do Rio Preto has average cost higher than Vale do Ribeira. The reason is that in the former region 
xvi i .

the fixed cost is higher, due to the use of machinery, while the latter region has a traditional production system. 


\section{INTRODUGÃO}

\subsection{A Heveicultura no Estado de São Paulo}

Em termos de heveicultura, o Estado de São Pau lo atende a prescrição do parägrafo 2\%, artigo 2: da Resolução 33/77, do Conselho Nacional da Borracha (CNB), que instituiu o "II Programa de Incentivo à Produção da Borracha Natural" (PROBOR II): ... "Os benefícios do programa poderão sen estendidos a outras regiões do Territōrio Nacional que reunam condiçōes ecolögicas favorāveis ao plantio da seringueira..." (20)

Embora o Estado de São Paulo não possua tradiçao na cultura da seringueira, ela aqui existe há mais de 40 anos, sendo que os primeiros estudos relacionados as condições climáticas da hevea datam de 1941, quando o Instituto Agronômico de Campinas (IAC) instalou as primeiras plantações nas Estações Experimentais de Campinas, Ribeirão Preto e Pindorama. 
Mas, foi com ó advento da indústria automobilís tica, na década de 1950, que o IAC houve por bem intensificar os estudos relativos à seringueira, quando seus pesquisadores observaram que não havia correspondência na produção de borra cha natural e o aumento do parque industrial do país. As Tabe las 23 e 24 do Apêndice 1 permitem comparar como evoluíram as produções internas de borracha natural e sintética.

A existência de seringueiras em vārios locais do Estado, seu ótimo desenvolvimento vegetativo e excelente as pecto sanitärio foram fatores que muito contribuíram para a tomada de posição por parte dos pesquisadores do IAC.

Assim è que, em 1952, um ano após a primeira importação de borracha efetuada pelo Governo Federal, providenciou-se a introdução, no país, de certa quantidade de sementes para dar inicio aos primeiros plantios racionais de se ringueira.

Embora uns poucos resultados em termos de produtividade e qualidade da borracha aqui produzida somente começassem a aparecer em 1957/58, em resposta à iniciativa do IAC criou-se, em São Paulo, o Serviço de Expansão da Seringueira, órgão subordinado à Secretaria de Agricultura de São Paulo. A Coordenadoria de Assistência Técnica Integral (CATI) e o Instituto Biológico, em estreita colaboração com o $\sqrt{A C}$, contribuíram com relevantes trabalhos na área de fitossa nidade, genética, fisiologia, tecnologia, etc...

As primeiras plantações em propriedades particulares foram realizadas no final da década de 50 , com mudas 
fornecidas pela própria Secretaria e sob orientação de pesqui sadores e técnicos envolvidos nos programas de fomento. Além de clones orientais importados foram trazidos, também, clones do Pará e da Bahia para a formação dos jardins clonais e enxertia de "cavalos" nos vi veiros formados.

Por razões diversas os programas de fomento en traram em recesso e o Serviço de Expansão da Seringueira, órgão responsável pelo fomento da cultura, chegou a distribuir, nessa época, cerca de $600 \mathrm{mil}$ mudas enxertadas, gratuitamente. Hoje os seringais do Estado de São Paulo totalizam 192.925 plan tas adultas, cuja distribuição geográfica é vista na Tabelá l.

Tabela 1 - Distribuição Geográfica dos Seringais Adultos no Estado de São Paulo em 1981.

\begin{tabular}{lcccc}
\hline Região & $\begin{array}{c}\text { No de } \\
\text { municipios }\end{array}$ & $\begin{array}{c}\text { No de } \\
\text { proprieda } \\
\text { des }\end{array}$ & $\begin{array}{c}\text { No de } \\
\text { seringuei } \\
\text { ras }\end{array}$ & $\begin{array}{c}\% \text { do } \\
\text { total de } \\
\text { seringueiras }\end{array}$ \\
\hline São José do. Rio Preto & 18 & 22 & 62.425 & 32,3 \\
Ribeirão Preto & 7 & 19 & 46.350 & 24,0 \\
Litoral & 9 & 22 & 41.880 & 21,7 \\
Presidente Prudente & 7 & 7 & 10.580 & 5,5 \\
Marilia & 4 & 6 & 10.590 & 5,5 \\
Bauru & 5 & 5 & 9.300 & 4,8 \\
Vale do Paraíba & 3 & 4 & 7.300 & 3,8 \\
Araçatuba & 1. & 1 & 3.000 & 1,6 \\
Campinas & 2 & 2 & 1.500 & 0,8 \\
\hline TOTAL & 56 & 88 & 192.925 & 100,0 \\
\hline
\end{tabular}

Fonte: PRO-BORRACHA (19). 
Em 1961, porem, o aparecimentó da moléstia "Mal-das-Folhas" causada pel.o Microcyclus ulei arrefeceu, sobremaneira, o entusiasmo que então reinava pela nova cultura. Daí em diante, as arremetidas em favor do estabelecimento de novos seringais ficaram em compasso de espera. Todavia, supe rado o primeiro impacto, os estudos foram retomados, merecendo destaque o trabalho realizado por CAMARGO (8) que, através de balanços hídricos e climáticos, demarcou as äreas consideradas aptas para o cultivo da seringueira em São Paulo. Os pa râmetros térmicos e hídricos fixados por CAMARGo (8) foram revistos, posteriormente, por ORTOLANI (16).

A Tabela 2 mostra as āreas e porcentagens das classes de aptidão ecológica para a seringueira. Conforme se observa, o total de zonas aptas ao cultivo da seringueira no Estado de São Paulo atinge $141 \mathrm{mil}$ quilómetros quadrados, equi valentes a 14 milhões de hectares.

Embora a régião litorânea esteja classificada como "apta com restrições", CARDOSO (9) é de opinião que a região apresenta boas possibilidades aos empreendimentos heveícolas, principalmente o iitoral sul, representado pelo Vale do Ribeira. Das mudas plantadas no Estado, no.final. de 1950 e início de 1960 , cerca de $22 \%$ encontra-se na região, onde estão sendo exploradas em caráter comercial.

As ārvores existentes no Estado que estão com, aproximadamente, 25 anos de idade permitiram, por muitos anos, uma avaliação do comportamento fenológico da serigueira no Es tado de São Paulo, evidenciando sua capacidade produtiva. 


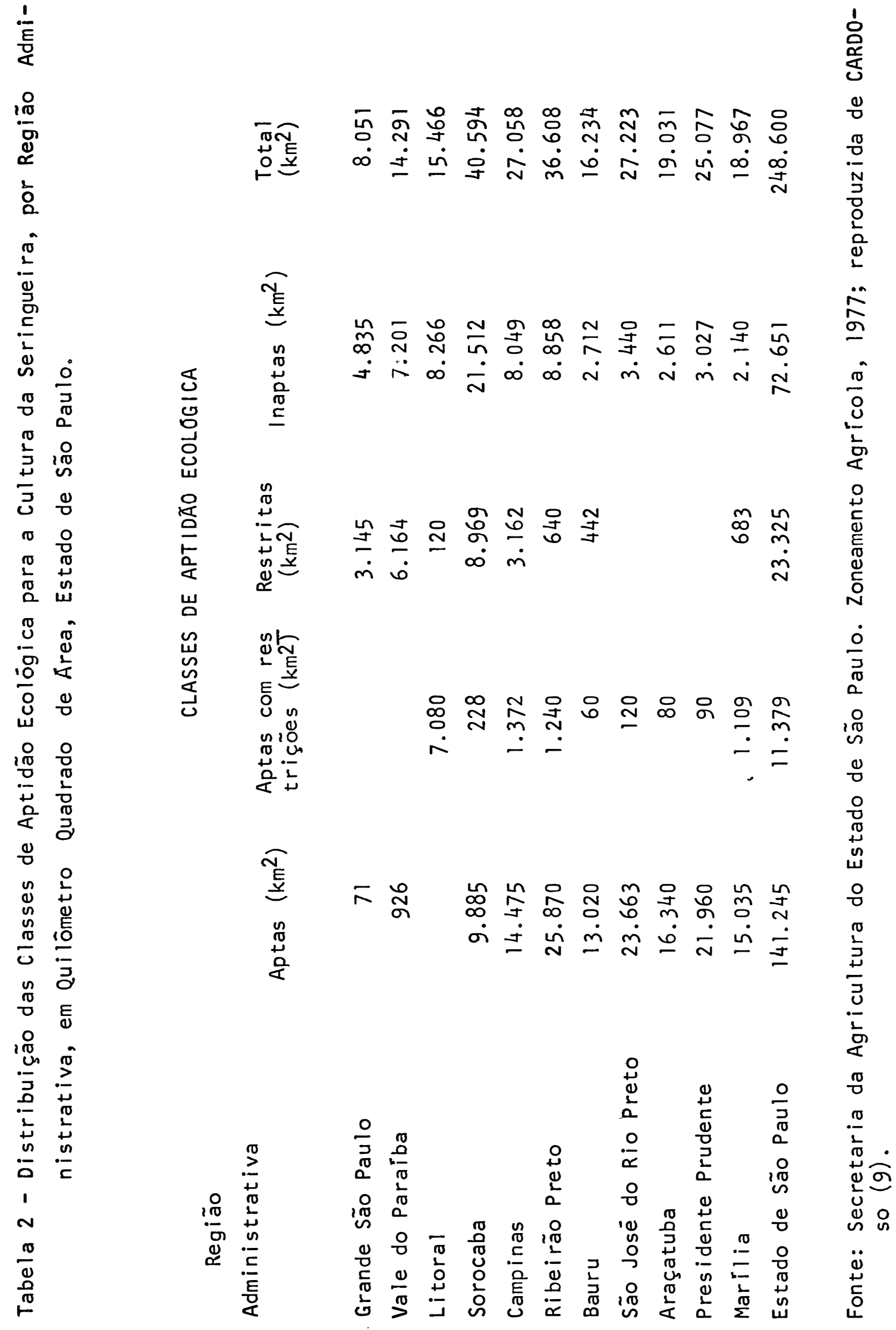


Após a primeira fase de fomento à heveicultura, o interesse foi retomado por volta de 1975. Isto porque, com as constantes elevações nos preços do petröleo, a borracha sintētica - cuja matēria-prima básica é o petróleo - teve seus preços elevados no mércado internacional, provocando maior procura pela borracha natural, cujos preços encontravam-se abai xo dos fixados para a borracha sintëtica. Dado o aumento con siderável na demanda da borracha natural, era de se esperar que os preços não permanecessem nos níveis vigentes até então. Passaram, sim, a acompanhar os preços da borracha sintética, provo cando uma euforia geral nos países produtores; no Brasil, os preços internos da borracha natural passaram a apresentar aumentos superiores às taxas inflacionārias. Motivados pelos altos retornos que a borracha poderia proporcionar, fazendeiros e empresários paulistas passaram a investir recursos próprios na aquisição de mudas e formação de seringais. Foi, tam bém, nessa época, que propriedades que tinham seringais adultos - plantados na primeira fase de fomento - passaram a explorä-los, de início, timidamente, devido à inexistência de mão-de-obra especializada para a sangria.

Contudo, com o apoio e incentivo de pesquisado res e tēcnicos da Secretaria da Agricultura e Abastecimento, nao só as deficiências foram superadas como conseguiram mot var o plantio de 6.746 .992 pés, correspondendo a uma área de 15.095 hectares, no período 1978\%85 (Tabela 3). Esses pés es tão distribuídos em 180 municípios do Estado. De 1978 a 1985 , 


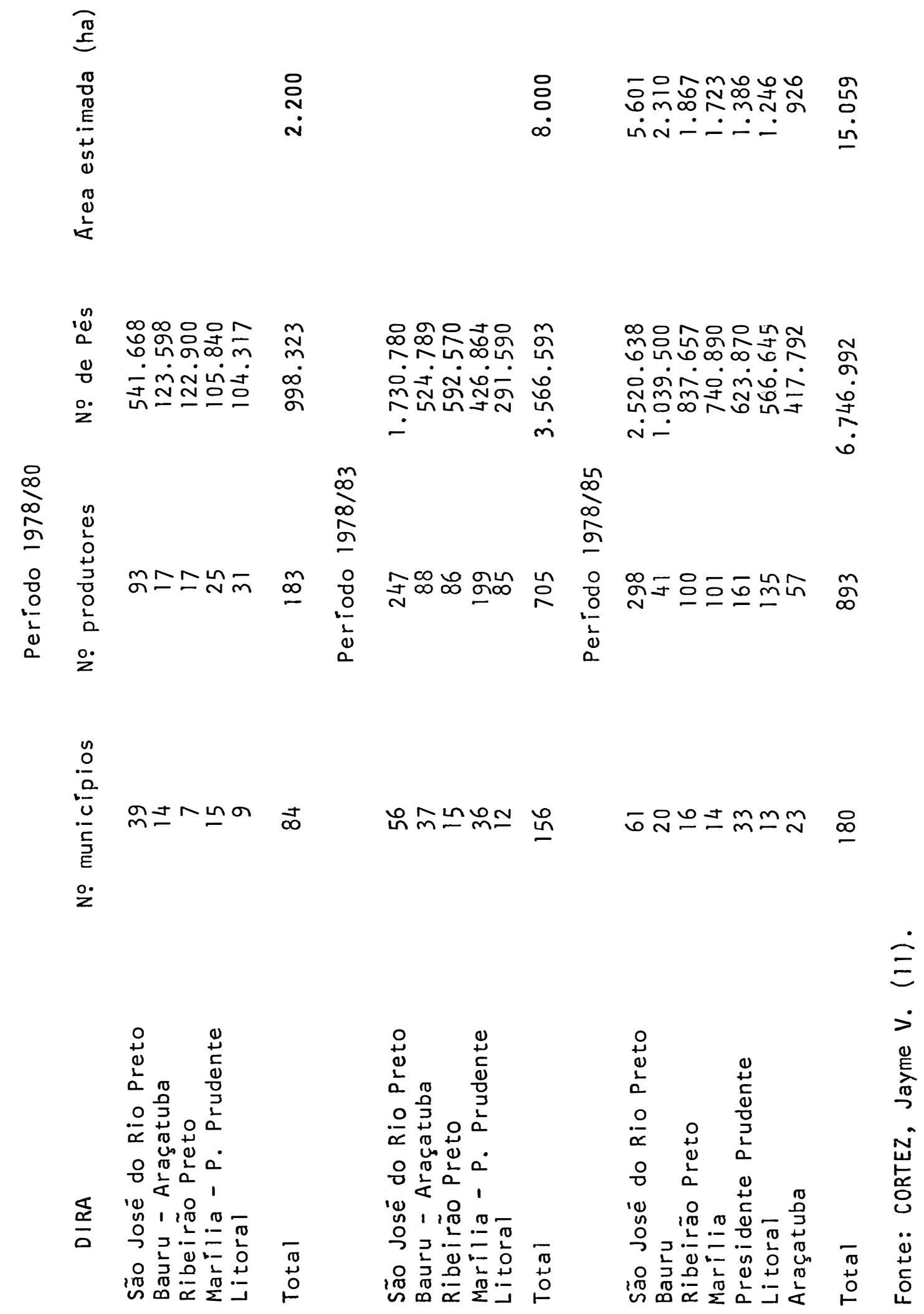


o número de pés e a área correspondente aumentaram em $580 \%$ e - número de produtores, que em $1978 / 80$ era 183, hoje totaliza 900 , com um aumento de $400 \%$.

Dos 15.095 hectares existentes, "1.070 hectares foram financiados pelo PROBOR III e os demais foram plantados com capital pröprio" (23).

\subsection{Importância do Problema e OBjetivos}

Um incremento da ordem de $580 \%$ na àrea plantada com seringueiras, num período de sete anos e com perspecti vas de um crescimento constante, passa a exigir do Estado uma polfitica direcionada ao setor, a fim de que não ocorra uma ex pansão desordenada e um provável desequilíbrio entre oferta e demanda.

Tal politica deve abranger um programa de pesquisas de carāter agronómico e econômico, assistência técnica eficiente e constante, formação de mão-de-obra especializada, difusão de tecnologia, etc.

Além dos aspectos técnicos, faz-se imprescindí vel o apoio governamental através de recursos financeiros, mor mente, na fase de implantação do seringal, bem como uma política de preços compatível com os custos de produção. Com o consumo interno de borracha natural aumentando mais do que a produção (ver Tabela 23 do Apêndice 1) è de se esperar que, pẹ 
10 menos a curto e médio prazos, os preços internos não se equalizem à cotação internacional (em abril de 1986 a relação era de $3 / 1)$, pois, se a meta governamental é atingir a autosuficiência o mais breve possível, hà que ser mantida, por algum tempo, a taxa que é paga pelos importadores brasileiros, denominada Taxa de Organização do Mercado de Borracha (TORMB) que, entre outros, tem como objetivo manter os preços internos em alta como incentivo à expansão da heveicultura. A guisa de informação, o Apêndice l mostra um cenário da produção e do consumo brasileiros de borracha natural. Porém, essa perspectiva do mercado futuro da borracha nacional, ainda incerto, tem que ser levada em consideração nos projetos que vierem a ser contratados. E de fundamental importância que os produtores interessados em investir na seringueira, tanto como forma de diversificar atividades já existentes ou com o objetivo de substituir outras culturas perenes, estejam cons cientes de que a atual euforia, pelos retornos que a borracha vem proporcionando, não deverá persistir por tempo indetermi nado.

Após estas considerações, conclui-se que è pre ciso conhecer as estruturas dos sistemas de produção em uso no Estado de São Paulo e proceder a uma anälise económica das mesmas, pois, como NEVES (14) observou, é na área econômica que a heveicultura mais se ressente de pesquisas principalmente, voltadas à Economia da Produção. 
Estudos nesse sentido levaram o Governo Federal, em 1979, a destinar recursos técnicos e financeiros à Superintendência da Borracha (SUDHEVEA) e à Empresa Brasileira de Pesquisa Agropecuāria (EMBRAPA). A preocupação do Governo Federal, a essa época, centrava-se em obter elementos que permitissem a caracterização dos sistemas de produção de borracha natural em seringais cultivados nos principais estados produtores brasileiros. Tais elementos, por sua vez, per mitiriam a obtenção de coeficientes técnicos de uso de fatores de produção, por meio dos quais seria possível estimar os cus tos médios de produção de borracha para um horizonte temporal de 27 anos e comparar os custos de produção da borracha cult vada com os custos de produção de borracha obtida de seringais nativos.

Este foi um trabalho pioneiro e de importância fundamental, pois a inexistência de pesquisas nesta ärea econômica, impedia o Governo de estabelecer preços mais realistas, uma vez que estes são administrados.

o levantamento dos dados, a nivel de proprieda de, foi efetuado pela Fundação de Estudos Agrários Luiz de Queiroz (FEALQ), Piracicaba, SP (que teve sob sua responsabilidade levantar dados de seringais financiados na região amazónica) e pelo Departamento de Economia Rural, da Universida de Federal de Viçosa, MG (a quem coube levantar os dados para as regiões não amazônicas). Os resultados obtidos nessa pesquisa encontram-se detalhados em NEVES et alii (15). 
Para a obtenção dos dados, a amostra foi estra tificada por tamanho de projeto. Para os Estados da Bahia, Espirito Santo e São Paulo, os estratos foram definidos como segue:

a) Propriedades com até 20 hectares de seringueiras;

b) Entre 20 e 100 hectares e

c) Propriedades com mais de 100 hectares.

Para a região amazónica, os projetos foram classificados como pequeno ou grande.

A preços de novembro de 1982 , os autores chegaram aos seguintes resultados: no Brasil, o custo médio por quilo de borracha extraída de seringais nativos era equivalen te a US\$2.75 e o custo médio por quilo de borracha extraída de seringais cultivados era equivalente a US\$ 1.45 .

Para São Paulo, particularmente, o custo total médio de produção foi de US\$1.42 (aquém da média brasileira) para uma taxa de desconto de $12 \%$ a.a., que representa - custo de oportunidade do capital pröprio. Este estudo não diferencia os dois sistemas de produção predominantes no Estado: o do litoral e o do planalto.

Alëm do trabalho citado, ARRUDA (1) realizou um trabalho de pesquisa onde procurou mostrar aspectos eco- 
nômicos da cultura da seringueira em São Paulo, no que diz respeito às exigências físicas de fatores de produção, para os períodos de formação e manutenção do seringal, dados sobre produtividade média por hectare, além de alguns töpicos sobre a comercialização do látex. Não se chegou a calcular o custo médio de produção de lātex para o horizonte temporal da cultụ ra.

o objetivo deste estudo é estender o trabalho realizado por ARRUDA (1), dando-se ênfase à determinação dos custos de produção de borracha natural para todo o horizonte temporal da cultura, em seringais cultivados nos sistemas de produção mais usuais, em duas regiões do Estado, quais sejam: a região litorânea (compreendendo o Vale do Ribeira) e o planalto paulista (região de São Josē do Rio Preto).

Especificamente, pretende-se:

- estimar os custos médios de produção, por hectare e por unidade produzida para cada sistema de produção (considerando trés níveis de produtividade por hectare), comparā-los entre si e entre regiões, utilizando as taxas de desconto de $6 \%$ a.a., $10 \%$ a.a.,12\% a.a. e $20 \%$ a.a., como custo de oportunidade do capital, e

- comparar os custos médios de produção, por hectare e por unidade produzida, com os resultados obtidos por NEVES et alii (15). 


\section{METODOLOGIA}

\subsection{Fonte de Dados e Amostra}

A fim de atender aos objetivos propostos, utilizou-se dados primários, coletados diretamente junto aos pro dutores, e dados secundários, que foram obtidos junto a pesquisadores e técnicos envolvidos com a heveicultura.

$$
\text { A pesquisa de campo foi realizada em 1982, }
$$

através de questionários previamente testados, nas regiões do Vale do Ribeira e São José do Rio Preto.

Escolheu-se estas regiões por apresentarem uma relativa concentração de seringais adultos em plena produção, remanescentes dos plantios realizados no final da década de 50 e inicio da década de 60 e a existência de seringais em fase de formação, plantados no final da década de 70 . Desse modo, dispunha-se de dados de seringais com mais de 20 anos de idade e de seringais em fase de formação; por ocasião do 
levantamento dos dados, 1982, a maioria destes seringais contava com quatro anos de idade.

Posteriormente, em setembro/outubro de 1985 , voltou-se a campo a fim de completar as informações referentes à formação e início de produção, que em são paulo se dá aos seis anos de idade.

Dados sobre o comportamento de seringais com idade entre sete e dez anos (quando se estabiliza a produção), foram obtidos através de literatura específica e de experimentos realizados em Estações Experimentais do IAC.

Para ambas as regiões pesquisadas, optou-se por uma amostragem internacional, pela necessidade de se obter dados sobre a cultura nos diversos anos de sua formação, a fim de se montar matrizes de coeficientes técnicos representa tivos de cada ano, inclusive de viveiro de mudas e de seringais adultos. Ainda, quanto à amostra ter sido intencional, um outro aspecto que se levou em consideração (no caso do planaltol foi saber, "a priori", que a maioria dos seringais estava sendo implantada com consorciamento de culturas anuais, principalmente, arroz, soja, amendoim e feijão. Desse modo, optou-se por obter maior quantidade de dados referentes a esta prática. Outros métodos, como oplantio "solteiro" e o plantio da seringueira nas entrelinhas de um cafezal em fase decadente, eram pouco usados na ocasião.

Já no vale do Ribeira, o consorciamento näo era uma prática usual, pois a maioria dos plantios foi 
realizado em terrenos acidentados, impröprios paraculturas anuais.

Em 1982, havia no Vale do Ribeira 22 proprieda des agrícolas com seringais, incluindo aquelas com plantios novos e propriedades com seringais de mais de vinte anos.

Desse nümero, foram levantados dados de 18 pro priedades, das quais 12 com seringueiras em fase de formação e 6 com ärvores adultas; destas ültimas, colheu-se dados de 29.300 ärvores que estavam sendo exploradas comercialmente.

Os municipios abrangidos foram os seguintes: Registro, Juquiá, Jacupiranga, Sete Barras, Pariquera-Açü e Cananéia (parte continental).

Na região de São José do Rio Preto o nümero es timado de propriedades era de 22 , das quais 14 foram entrevistadas. Essas propriedades localizavam-se nos municipios de Poloni, José Bonifácio, Tabapuã, Bälsamo, Nhandeara e Olím pia.

Levantou-se dados de 9 propriedades com seringais em formação e 5 com seringais adultos, totalizando 32.000 plantas em franca produção.

Com as informações disponiveis foi possivel montar matrizes de exigências físicas de fatores para cada região, representativas dos sistemas de produção vigentes na região litorânea e planalto, que se encontram em anexo (Apên dice 2). 
Verifica-se, atravēs das matrizes, que as distinções entre os sistemas de produção das duas regiões referem-se, apenas, ao primeiro ano de investimento, pois, do segundo ano em diante as operações realizadas são comuns tanto num sistema como no outro, uma vez que se referem a tratos culturais.

As caracteristicas regionais e os sistemas de produção são descritos no Apêndice 2 .

\subsection{Método de Calculo do Custo de Produgão}

Para calcular os custos de produção por hectare e por unidade produzida utilizar-se-á a teoria de investimento em bens de produção, usada por NEVES et alii (15).

A exploração heveícola é um investimento de longo período de maturação. No início são feitos os investimentos (cinco ou seis primeiros anos) e somente a partir do sexto ou sëtimo ano os seringais entram em fase de produção. Desse modo, todas as despesas efetuadas com a cultura nos pri meiros cinco ou seis anos representam os cursos de investimen to. A partir do início da produção as despesas incorridas re presentam os custos de exploração do seringal. Portanto, é ne cessário compatibilizar o fluxo de dispendio monetärio com o fluxo de produção anual, durante a vida útil da seringueira, para se obter o custo por unidade produzida. 
Para tornar comparáveis os fluxos de despesas monetárias no tempo optou-se pelo cálculo do custo anualizado de produção.

No presente trabalho o horizonte temporal considerado ë de vinte e sete anos, de acordo com critério usado por NEVES et alii (15); o periodo de implantação ou investimento do seringal considera-se atè o quinto ano e o ciclo de produção ou exploração á partir do sexto ano prosseguindo até o vigësimo sétimo ano.

Tem-se, portanto, cinco anos de implantação e vinte e dois anos de exploração. O inicio do sexto ano é con siderado como data. base ou ano "zero" do ciclo de produção de borracha.

Seja $D_{t}$ a despesa, por hectare, com o projeto no ano $t$, que se considera antecipada, isto é, realizada no início do ano.

o valor de todas as despesas referido ao inicio do sexto ano do projeto è:

$$
\sum_{t=1}^{27} D_{t}(1+r)^{-(t-6)}=\sum_{t=1}^{27} D_{t}(1+r)^{6-t}
$$

Seja $R_{t}$ o rendimento em litro de lätex ou quilo de borracha seca por hectare no ano $t$.

Seja C o preço real que permitirà que a receita bruta anualizada iguale os custos do projeto. Então C representa o custo médio por unidade do produto. 
Admitindo que as receitas também são antecipadas, tem-se:

$$
\text { c } \sum_{t=6}^{27} R_{t}(1+r)^{6-t}=\sum_{t=1}^{27} D_{t}(1+r)^{6-t}
$$

ou

$$
c=\frac{\sum_{t=1}^{27} D_{t}(1+r)^{6-t}}{\sum_{t=6}^{27} R_{t}(1+r)^{6-t}}
$$

o custo médio, pór unidade do produto, assim definido, independe do ano que è utilizado como ponto de referência para acumular custos e receitas.

Pode-se tambēm definir o custo anual médio por hectare (A) como a prestação anual, durante os 22 anos de exploração da cultura que equivale, com a taxa de juros adotada, ao total das despesas.

Então,

$$
A \frac{(1+r)^{22}-1}{r(1+r)^{22}}=\sum_{t=1}^{27} D_{t}(1+r)^{6-t}
$$

ou

$$
A=\frac{r(1+r)^{22}}{(1+r)^{22}-1} \cdot \sum_{t=1}^{27} D_{t}(1+r)^{6-t}
$$


Analogamente, pode-se definir como rendimento anual médio o valor B, tal que

$$
\text { B } \frac{(1+r)^{22}-1}{r(1+r)^{22}}=\sum_{t=6}^{27} R_{t}(1+r)^{6-t}
$$

Observando que os rendimentos são nulos até o inicio do 6: ano. 0 valor de $B$ será obtido pela expressão

$$
B=\frac{r(1+r)^{22}}{(1+r)^{22-1}} \cdot \sum_{t=6}^{27} R_{t}(1+r)^{6-t}
$$

è fäcil verificar que $C=\frac{A}{B}$.

De acordo com o modelo, os valores são constantes, comparäveis no tempo atravês de índices como OTN ou convertendo-se em dólares.

Critërios bäsicos que serão utilizados no cälculo do custo de produção:

a) Como despesas de investimento serão considerados tanto os custos fixos como os custos variáveis, que ocorrem durante o período de implantação.

b) Todos os fluxos de despesas serão expressos no texto em cruzeiros de maio de 1985; nas Tabelas, os valores serão apresentados em mil cruzeiros.

c) Utilizar-se-á como taxa mínima de atratividade (ou custo de oportunidade do capital próprio) à taxa de $12 \%$ a.a., em termos reais. 
d) 0 valor residual dos investimentos no 27 . ano serà considerado desprezivel.

e) Dada as medidas econômicas baixadas pelo Go verno Federal em 28 de fevereiro de 1986, impossibilitando uma estimativa de taxas inflacionärias, pelo menos no curto e médio prazos, recalcular-se-á o custo médio às taxas de $6 \%$ a.a., $10 \%$ a.a. e $20 \%$ a.a.. A taxa de $6 \%$ a.a. equivale à remuneração anual das cadernetas de poupança e a de $10 \%$ a.a. corresponde a taxa de juros do crēdito rural para a região Centro-sul do Pais. Tendo em vista que a heveicultura é uma atividade considerada de alto risco considerar-se-ä, ainda, a taxa de $20 \%$ a.a, para maior segurança do investidor.

f) Para o cálculo dos itens de custos fixos e variäveis serão utilizados os critërios adotados por ROSOLEN e RAMOS (22) e por NEVES et ali i (15).

\subsection{Definigão e Determinacão dos Custos de Producão}

Entende-se por custo de produção toda remunera ção dos recursos produtivos utilizados na obtenção de um determinado bem.

Os custos dividem-se em fixos e variáveis. Os custos fixos referem-se à remuneração dos fatores fixos de produçāo, que são constantes e independem de qualquer variação no volume produzido, por unidade de tempo. Os custos va- 
riăveis são os dịspêndios efetuados para remunerar os fatores variáveis de produção, variando de acordo com o aumento ou di minuição da quantidade produzida do bem.

A soma destes itens de custo perfaz o custo total de produção.

Para se calcular os itens de custos para a cul tura da seringueira, levou-se em consideração a fase de implantação da cultura e os periodos de maturação e produção e/ ou exploração.

Na fase de implantação a definição das variáveis obedeceu aos seguintes critērios:

- Administração e benfeitoria: com base nos dä dos constantes dos questionärios, calculou-se a àrea média cultivada nas propriedades pesquisadas no Vale do Ribeira e São Josè do Rio Preto. Para o Vale do Ribeira obteve-se uma ärea mëdia de 116 hectares e para o planalto, 131 hectares.

Os questionārios revelaram, tambēm, que tais äreas exigiam, em mëdia, duas casas de empregado e um admini $\underline{s}$ trador residente na propriedade, além de um galpão para máqui nas e equipamentos. Para obter-sé os valores dos imóveis (cá sas de empregados), por hectare, dividiu-se os valores dos mes mos, estimados em Cr\$10.500.000 (em maio de 1985), pelas äreas mêdias de cada região. Os valores encontrados foram de Cr\$90.250 para o Vale do Ribeira e Cr\$80.150 para São Josè do Rio Preto.

Para chegar à remuneração do administrador, to 
mou-se como base o salário mëdio mensal do tratorista, acrescido de $30 \%$, de acordo com informações obtidas junto aos tēcnicos extensionistas das regiões pesquisadas. Calculado o sa lário anual, este foi dividido pela área média cultivada do estabelecimento para obter os valores por hectare. Para o Vale o salärio médio por halano foi de Cr\$50.430 e para São José do Rio Preto foi de Cr\$80.150.

Para efeito de cálculo do custo fixo, o investimento realizado em galpão näo foi considerado, visto que seu valor já está embutido nos custos diărios de máquinas, cons tantes das matrizes de coeficientes técnicos que se encontram em anexo (Apêndice 2).

- Māquinas e equipamentos: o critērio para o cálculo do custo foi o mesmo adotado para o item "Administra ção e benfeitorias". Contudo, neste caso, os dados da pesquisa mostraram que a àrea média para um trator de $61 \mathrm{HP}$ era de 48 hectares. Desse modo, o valor do investimento em maqui narias, para um hectare de seringueira, foi equivalente a $1 / 48$ do valor dos equipamentos novos.

Para o cälculo dos juros sobre o capital inves tido em benfeitorias e máquinas, considerou-se a taxa de $6 \%$ ao ano sobre o valor correspondente a um hectare, procurando representar o uso alternativo deste capital. A taxa de $6 \%$ ao ano equivale à remuneração das cadernetas de poupança que, desde a sua instituição, manteve-se inalterada.

- Terra: sobre o valor mēdio, por hectare, da 
terra nua de primeira e segunra qualidades coletado pelo IEA (13), atribuiu-se a taxa de. $6 \%$ ao ano, conforme critério es clarecido.

Os valores referentes à remuneração com administração, benfeitorias e terra foram computados ao longo de todo o horizonte temporal, sem variação.

Quanto à remuneração do capital investido em maquinarias, considerou-se um valor até o décimo ano (vida útil estimada em dez anos) e um valor diferenciado a partir do dècimo primeiro ano até o tèrmino do projeto. Explica-se este valor diferenciado pelas próprias características da cul tura que, ao atingir a plena maturação torna-se pouco exigente em tratos culturais, dispensando a maioria dos equipamen tos utilizados na fase de formação. Neste segundo período re munerou-se, apenas, o investimento feito na aquisição de um trator e uma enxada rotativa.

Este procedimento foi adotado apenas para os sistemas de produção da região de São José do Rio Preto, pois os sistemas mais usuais do Vale do Ribeira não utilizam maqui narias, uma vez que os plantios são feitos em morros. os demais itens, porēm, receberam o mesmo tratamento, ou seja, os critérios utilizados para remuneração dos fatores fixos foram os mesmos em ambas as regiões.

Assim, com exceção do primeiro ano, onde computaram-se os valores de construção de benfeitorias e aquisição de máquinas, os custos fixos são, praticamente, constantes até o final do projeto. 
Como itens de custo variăvel incluiram-se as seguintes despesas: mão-de-obra, combustivel e lubrificantes, mudas, corretivo e fertilizantes, reparos de benfeitorias e mäquinas. No caso de mäquinas, a parcela referente a reparos jả està computada-no-custo di-ärio.

- Mão-de-obra: foram considerados valores diferenciados para a mão-de-obra comum e tratorista, obtidos por ocasião do quarto levantamento de previsão de safras realizado pelo IEA, cujos dados são coletados, anualmente, nomês de abril e tambēm, atravēs de informações coletadas nas regiões produtoras em sindicatos rurais e cooperativas, e consi derando o reajuste do salärio mínimo no mês de maio. os dados referentes aos valores de mão-de-obra coletados pelo IEA, não säo divulgados mensalmente.

- Mudas, corretivo e fertilizantes: os preços considerados foram os que vigoraram nas próprias regiões, for necidos por viveiristas - no caso de mudas - e por técnicos da Secretaria de Agricultura e Abastecimento e por cooperativas de produtores.

- Combustível e lubrificante: os preços foram os do mês "base" (maio de 1985).

- Reparos de benfeitorias: a parcela correspon dente a reparos de benfeitorias representa $5 \%$ do valor das mesmas, conforme critério usado por NEVES et alii (15). 


\subsection{Produtividade dos Seringais Paulistas}

Os dados sobre produtividade, em $\mathrm{ml} / \mathrm{sangria} e$ litros de látex/hectare/ano dos seringais que se encontram em exploração, foram obtidos diretamente dos produtóres entrevís tados. As produtividades que constam das matrizes de coeficientes tëcnicos, tanto para o Vale do Ribeira como para são Josë do Rio Preto, foram obtidas de dados de produção do ano de 1981. Esses dados constam de planilhas que são distribuidas aos produtores pelas Casas de Agricultura. As anotações, feitas diariamente, referem-se ao nümero de árvores san gradas por dia e à produção obtida. Com base nessas informaçōes calculou-se a produtividade, ml/sangria em/hectare/ano, considerando uma média de 400 ärvores por hectare.

Os dados obtidos de 2.000 litros de lätex por hectare para o Vale do Ribeira e de 2.800 litros para São José do Rio preto são dados de produção dos seringais plantados hà mais de 25 anos.

Esses números säo considerados baixos por tēcnicos ligados à heveicultura, pois, a pesquisa com a hevea em São Paulo mostra dados de produção que se aproximam de 4.000 litros por halano. Contudo, a produção que está se obtendo dos seringais antigos tem uma explicação: por ocasião da distribuição das mudas formadas pela Secretaria da Agricultura não houve um cadastramento dos clones existentes e muitos dos produtores que receberam as mudas não tiveram a preocupação 
de pesquisar a origem. Assim, esses seringais, na maioria, contam com grande diversificação clonal, alguns com boa produção e outros com baixa produção, alêm da exístência de "pés francos". Tambēm não houve preocupação em se manter um "stand" uniforme. Com o espaçamento de $7 \mathrm{~m} \times 3 \mathrm{~m}$, um hectare comporta 476 árvores, porēm, esse nümero não foi mantido, dado que não se pensava, na ocasião, em exploração comercial. Ademais, esses seringais näo receberam os tratos culturais recomendados, que também influem na produção. Mas, talvez o moti vo mais importante, responsável pela baixa produtividade, tenha sido a falta de mão-de-obra especializada em sangria. E comum observar, nesses seringais, ärvores completamente danificadas devido ao desconhecimento da técnica de sangria. Essas considerações, a lēm de esclarecerem a produtividade obtida, explicam, tambèm, a mēdia de 400 ärvores por hectare, como consta das matrizes de coeficientes tëcnicos.

As falhas observadas no passado, estão sendo corrigidas por todo corpo técnico envolvido com a heveicultü ra em São Paulo, alēm da preocupação em assistir melhor aos produtores. Nos meses de agosto e setembro de 1985, os escritoorios regionais da SUDHEVEA em são Paulo constituíram uma comissão composta por pesquisadores dos diversos institutos de pesquisa de São Paulo, por tēcnicos extensionistas, produtores rurais, professores e alunos de cursos de pós-graduação da Escola Superior de Agricultura "Luiz de Queiroz" (ESALQ), com o objetivo de "montar" o sistema de produção da seringue 
ra para o Estado de São Paulo. Esse estudo, após sua publicação e divulgação, servirà como subsídio băsico àqueles interessados no plantio da seringueira.

Além dos esforços dos pesquisadores paulistas e da pröpria SUDHEVEA, São Paulo conta com o apoío da EMBRAPA, atravès do seu Centro Nacional de Pesquisas de Jaguariüna, que montou um núcleo destinado a levantar os problemas da cultura no Estado e dar orientaçāo aos produtores, além de intensificar as pesquisas em conjunto com outros örgãos.

Com os novos conhecimentos divulgados pela pes quisa e com uma assistência técnica eficiente e constante po derá ocorrer ganhos de produtividade.

Para fins de cálculo do custo anualizado médio de produção de borracha (litros de lätex ou quilo de borracha por ha/anol e custo mëdio por hectare, considerou-se três níveis de produtividade: uma produtividade mínima, uma média e outra máxima.

A produtividade mínima vem a ser a obtida atra vés dos dados levantados em campo; a média é um nível de produtividade considerado perfeitamente possivel de ser consegui do pela maioria dos produtores que deverão começar a sangria dentro de dois a três anos; a máximá, è um nível considerado ötimo e poderá vir a ser conseguida por alguns poucos produtores que dispõem de recursos financeiros para treinamento de mão-de-obra na fase de sangria, tanto quanto, contar com assistência tècnica permanente. 
os dados utilizados para calcular as produtivi dades denominadas "média e máxima" foram obtidos de produtores que dispõem de seringais com sete anos de idade e de técnicos ligados à atividade heveícola. Tomando-se as produções obtidas no sexto e sëtimo ano, ml/sangria, bem como o número de árvores que entraram em produção no sexto ano, chegou-se aos dados que deverão vigorar no dëcimo ano, considerado de estabilização.

Na Tabela 4, tem-se a produtividade, $\mathrm{ml} / \mathrm{sang}$ ria, do sexto ao décimo ano para os três níveis considerados e para as regiões do Vale do. Ribeira e São José do Rio Preto.

A fim de simplificar os cälculos, pressupōs-se idênticas variações entre os anos, tanto para a região litorâ nea como para o planalto, quando na verdade, essas variações dependem de interação genötipo x ambiente.

A produtividade por sangria, de um ano para ou tro, depende tambēm do perímetro do caule. Pode-se supor um seringal com 400 àrvores, das quais 100 ärvores jä estão com perimetro acima de $45 \mathrm{~cm}$, que è o tamanho ideal para se iniciar a sangria. Das 100 àrvores, algumas podem estar com 45 $\mathrm{cm}$ de perimetro e outras com até $50 \mathrm{~cm}$ ou, ainda, supor que - produtor tenha iniciado a sangria de outras tantas ärvores con perimetro inferior à $45 \mathrm{~cm}$. Nesse caso, a produtividade obtida dessas 100 ärvores será variável de um seringal para outro (supondo que foram enxertados com um mesmo genótipo), pois depende da quantidade de vasos leticíferos, cu- 
Tabela 4 - Produtividade Esperada, ml/Sangria, em Seringais Cultivados, para as Regiões do Vale do Ribeira e São Josē do Rio Preto, Estado de São Paulo.

\begin{tabular}{|c|c|c|c|c|c|c|c|c|}
\hline \multirow{2}{*}{ Região } & \multirow{2}{*}{$\begin{array}{l}\text { Nível de } \\
\text { produtividade }\end{array}$} & \multicolumn{6}{|c|}{ ANO } & \\
\hline & & $6:$ & $7:$ & $8:$ & $9:$ & $10 \%$ & & $27{ }^{\circ}$ \\
\hline \multirow{3}{*}{ Vale do Ribeira } & Mínimo & 15,0 & 19,4 & 32,2 & 36,5 & 40,0 & $\ldots$ & 40,0 \\
\hline & Mëdio & 19,0 & 24,3 & 40,3 & 45,5 & 50,0 & $\ldots$ & 50,0 \\
\hline & Māximo & 26,4 & 34,0 & 57,0 & 64,0 & 70,0 & $\ldots \ldots$ & 70,0 \\
\hline \multirow{3}{*}{ S.José do Rio Preto } & Mínimo & 20,9 & 27,0 & 45,0 & 51,0 & 56,0 & $\ldots$ & 56,0 \\
\hline & Médio & 26,4 & 34,0 & 57,0 & 64,0 & 70,0 & $\ldots$ & 70,0 \\
\hline & Mäximo & 35,0 & 45,0 & 75,0 & 85,0 & 94,0 & $\ldots$. & 94,0 \\
\hline
\end{tabular}

Fonte: Informação obtida de produtores e técnicos ligados à heveicultura. 
jo nümero varia tanto com a idade da planta como com - perimetro.

POLHAMUS (18) citado por VIRGENS e CASTRO (26) p.274, afirma que "o nümero de anêis dos vasos laticíferos é uma caracteristica clonal e varia com a idade da planta, podendo ser um número de um a dois em plantas jovens ou até mais que cinqlenta em determinadas plantas adultas".

Com base nos dados da Tabela 4 e com as considerações expostas montou-se a Tabela 5 , que mostra a produtividade esperada, I/látex por hectare/ano, para seringais cultivados no Estado de São Paulo. Contudo, para efeito de cálculo dos custos unitários os dados foram corrigidos para as diferentes taxas de desconto, como mostra a Tabela 6 . 
Tabela 5 - Produtividade Esperada, l lätex/ha/ano, em Seringais Cultivados, para as Regiões do Vale do Ribeira e São José do Rio Preto, Estado de São Paulo.

\begin{tabular}{|c|c|c|c|c|c|c|c|c|}
\hline \multirow{2}{*}{ Região } & \multirow{2}{*}{$\begin{array}{c}\text { Nível de } \\
\text { produtividade }\end{array}$} & \multicolumn{6}{|c|}{ ANO } & \multirow[b]{2}{*}{$27:$} \\
\hline & & 60 & $7:$ & $8 \%$ & $9 \%$ & $10 \%$ & & \\
\hline \multirow{3}{*}{ Vale do Ribeira } & Minimo & 187 & 485 & 1.610 & 1.825 & 2.000 & $\ldots \ldots$ & 2.000 \\
\hline & Mëdio & 237 & 608 & 2.015 & 2.275 & 2.500 & $\ldots$. & 2.500 \\
\hline & Mäximo & 330 & 850 & 2.850 & 3.200 & 3.500 & $\ldots$. & 3.500 \\
\hline \multirow{3}{*}{ S. José do Rio Preto } & Mínimo & 262 & 675 & 2.250 & 2.550 & 2.800 & $\ldots$ & 2.800 \\
\hline & Mëdio & 330 & 850 & 2.850 & 3.200 & 3.500 & $\ldots$ & 3.500 \\
\hline & Mäximo & 437 & 1.125 & 3.750 & 4.250 & 4.700 & $\ldots$ & 4.700 \\
\hline
\end{tabular}

Fonte: A partir dos dados da Tabela 4 e de informações obtidas de produtores e técnicos ligados à hevei cultura. 
Tabela 6 - Produtividade Corrigida, $\ell$ lätex/ha/ano, para Efeito de Cálculo dos Custos Unitários, para Diferentes Taxas de Desconto, Regiões do Vale do Ribeira e São José do Rio Preto, Estado de São Paulo.

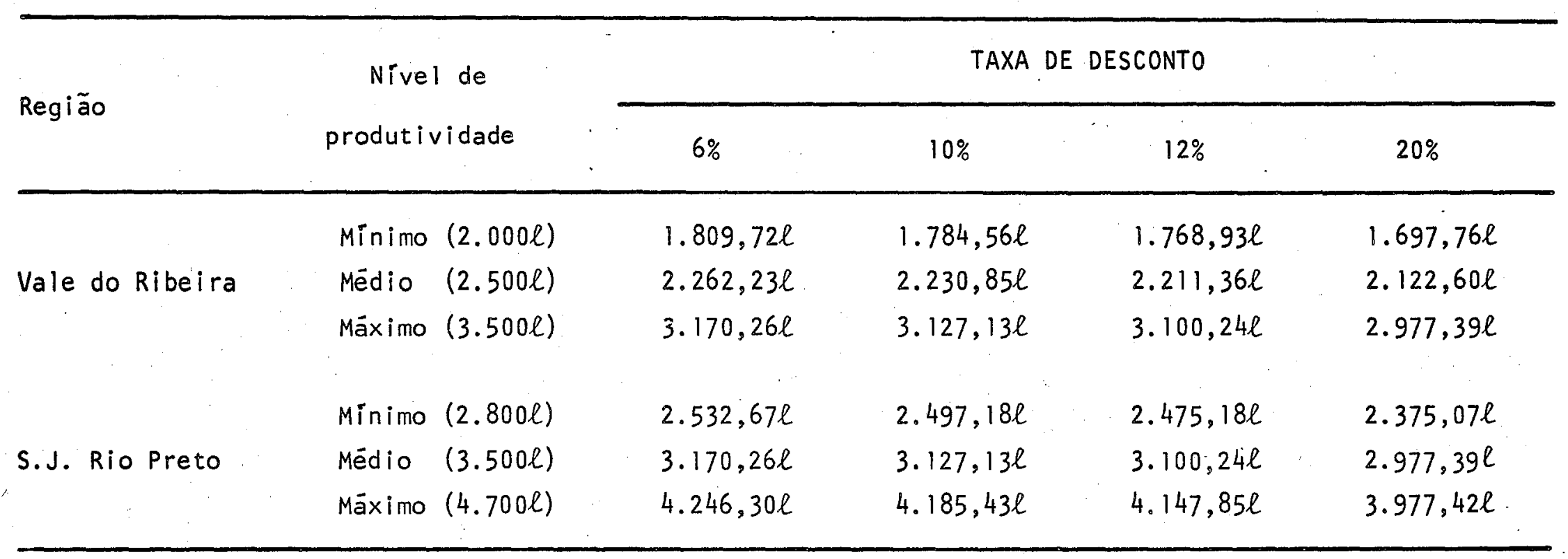




\section{RESULTADOS E DISCUSSÃO}

0s resultados obtidos, que permitirão analisar os custos médios anualizados de produção de látex e de borracha por hectare e por unidade produzida, serão comentados, in cialmente, considerando os diferentes sistemas de produção em uso em cada uma das regiões pesquisadas, utilizando a taxa de $12 \%$ ao ano, como custo alternativo do capital empregado no cultivo da seringueira. Em seguida, serão discutidos os resultados obtidos com taxas de desconto de $6 \%, 10 \%$ e $20 \%$ ao ano. Prosseguindo a análise, pretende-se comparar os cus tos de produção dos seringais cultivados no Vale do Ribeira e na região de São José do Rio Preto e, finalmente, far-se -à uma comparação entre os resultados do presente trabalho com os resultados conseguidos por NEVES et ali i (15). Os va lores serão apresentados em cruzeiro de maio de 1985. 


\subsection{Custos médios de Produgão de látex e de Borracha Seca para a Região do Vale do Ribeira e São Jose do Rio Preto}

Como consta do Apêndice 2, foram identificados dois sistemas de produção no Vale do Ribeira, quais sejam: plantio da muda com raiz nua, adquirida de viveirista particular e plantio de muda formada em viveiro próprio, destacan do-se o primeiro sistema como o mais usual por ocasião do levantamento dos dados.

Calculados os custos médios anualizados de pro dução por hectare, para os dois sistemas, a anälise dos resul tados mostrou que os custos de produção são mais baixos quando o produtor forma a pröpria muda, ao invês de comprá-la de viveirista particular (Tabela 7). Embora, para formar a muda, a exigência em termos de mão-de-obra seja $38 \%$ a mais do que exigiria se o produtor optasse em comprä-la, o montante gasto para remunerar a mão-de-obra (cerca de 85 dias de serviço no primeiro ano de implantação) é inferior ao desembolso caso adquirisse as mudas de particulares, como pode ser constatado analisando os dados das Tabelas 26 e 27 do Apêndice 2 .

Os custos variáveis, que englobam as despesas com mão-de-obra, insumos, equipamentos e reparo de benfeitorias, têm uma participação de $87 \%$ e $86 \%$ do custo total anuali zado, por hectare, à taxa de desconto de $12 \%$ ao ano, respecti vamente, para o primeiro e o segundo sistemas de produção. Es 
Tabela 7 - Custo Médio Anualizado de Produção de Seringais, por Hectare, sob Diferentes Taxas de Desconto, para Dois Sistemas de Produção, Vale do Ribeira, Estado de São Paulo (em mil cruzeiros de Maio de 1985).

\begin{tabular}{|c|c|c|c|c|c|c|c|c|}
\hline & $6 \%$ & & $10 \%$ & & $12 \%$ & & $20 \%$ & \\
\hline produção & $\begin{array}{l}\text { Valor presente } \\
\text { anualizado }\end{array}$ & $\%$ & $\begin{array}{c}\text { Valor presente } \\
\text { anualizado }\end{array}$ & $\%$ & $\begin{array}{c}\text { Valor presente } \\
\text { anualizado }\end{array}$ & $\%$ & $\begin{array}{c}\text { Valor presente } \\
\text { anual izado }\end{array}$ & $\%$ \\
\hline
\end{tabular}

\section{9 caso}

Aquisição de mudas

enxertadas

1. 1. Custo variāvel

1.2. Custo fixo

TOTAL

$\begin{array}{rrrrrrrr}2.553,72 & 88 & 2.857,74 & 87 & 3.044,89 & 87 & 4.084,92 & 86 \\ 341,29 & 12 & 413,70 & 13 & 457,35 & 13 & 688,43 & 14 \\ 2.895,01 & 100 & 3.271,44 & 100 & 3.502,24 & 100 & 4.773,35 & 100\end{array}$

\section{Caso}

Mudas enxertadas em

viveiro pröprio

2.1. Custo variāvel

$\begin{array}{rr}2.493,27 & 88 \\ 341,29 & 12 \\ 2.834,55 & 100\end{array}$

$2.757,86$

413,70

$2.919,48$

457,35

$3.171,56$

$3.376,83$

86

$3.809,21 \quad 85$

2.2. Custo fixo

$2.834,55$

100

100

688,43

15

TOTAL

.

.


tas participações não variam muito quando os custos são calcu lados às taxas alternativas.

Os coeficientes técnicos de fatores de produção constantes nas referidas tabelas mostram que o gasto com aquisição de mudas representa cerca de $60 \%$ do custo variável enquanto a remuneração da mão-de-obra, no caso do produtor formar a muda, representa, aproximadamente, $35 \%$. Como já foi comentado, o custo total de produção para o produtor que adqui re as mudas ë superior ao custo para a formação das mudas em viveiro próprio. A diferença entre um sistema e outro varia de $2 \%$, quando calculado à taxa de $6 \%$ ao ano, até $6 \%$, quando a taxa de desconto é de $20 \%$ ao ano.

os custos mëdios de produção, por unidade produzida, ou seja, por litro de látex, são apresentados na Tabe 1 a 8, para três níveis de produtividade por hectare. Esses ní veis de produtividade foram considerados conforme explanação feita no capitulo 2 , adotando-se este procedimento para forne cer maiores informaçōes aos produtores de borracha e aos örgãos envolvidos com a atividade heveícola.

o fato de se ter produtividades distintas não implica em se ter custos médios, por hectare, diferenciados, pois, maiores ou menores produtividades estão relacionadas com as variedades clonais plantadas e com o treinamento do "sangrador".

Os custos médios de produção de lätex, calculạ dos à taxa de desconto de $12 \%$, são maiores para o produtor que 
Tabela 8 - Custo Médio Anualizado de Produção, por li $i_{0} t r o$ de látex, para Três Níveis de Produtividade por hectare, em Dois Sistemas de Produção, Vale do Ribeira, Estato de São Paulo (em mil cruzeiros de Maio de 1985).

\begin{tabular}{|c|c|c|c|c|c|}
\hline \multirow{2}{*}{$\begin{array}{c}\text { Sistema de } \\
\text { produção }\end{array}$} & \multirow{2}{*}{$\begin{array}{c}\text { Nivel de } \\
\text { produtividade }\end{array}$} & $6 \%$ & $10 \%$ & $12 \%$ & $20 \%$ \\
\hline & & $\begin{array}{c}\text { Valor Presente } \\
\text { anualizado }\end{array}$ & $\begin{array}{c}\text { Valor Presente } \\
\text { anualizado }\end{array}$ & $\begin{array}{c}\text { Valor Presente } \\
\text { anualizado }\end{array}$ & $\begin{array}{c}\text { Valor Presente } \\
\text { anualizado }\end{array}$ \\
\hline \multicolumn{6}{|l|}{10 Caso } \\
\hline Aquisição de muda & Mínimo & 1,60 & 1,83 & 1,98 & 2,81 \\
\hline \multirow[t]{2}{*}{ enxertada } & Mēdio & 1,28 & 1,47 & 1,59 & 2,26 \\
\hline & Mäximo & 0,91 & 1,05 & 1,13 & 1,60 \\
\hline \multicolumn{6}{|l|}{29 Caso } \\
\hline Mudas enxertadas & Mínimo & 1,58 & 1,79 & 1,93 & 2,68 \\
\hline \multirow[t]{2}{*}{ em viveiro pröprio } & Mëdio & 1,26 & 1,43 & 1,53 & 2,13 \\
\hline & Mäximo & 0,90 & 1,02 & 1,09 & 1,52 \\
\hline
\end{tabular}


adquire a muda jä formada do que para o produtor que forma a pröpria muda. Ao nível de produtividade "mínima", ou seja, a produtividade realmente observada por ocasião da pesquisa de campo, os custos alcançaram valores de Cr\$1.980 e Cr\$1.930 por litro de látex, respectivamente, para o primeiro e segundo sistemas de produção. Entretanto, esses custos poderão ser inferiores na medida em que haja empenho, tanto por parte dos produtores como por parte dos örgãos de assistência téc nica, em conseguir ganhos de produtividade. Nesse caso, os resultados mostram para os níveis "mēdio" e "máximo" custos equivalentes a $\operatorname{Cr} \$ 1.590$ e $\operatorname{cr} \$ 1.130$, para o primeiro sistema de produção, e custos de Cr\$1.530 e Cr\$1.090 para o segundo.

A Tabela 9 mostra os custos médios anualizados de produção, por hectare, para três sistemas de produção, para seringais cultivados na região de São José do Rio Preto, no planalto paulista.

0 sistema de produção que apresenta custos mëdios mais elevados $\hat{e}$ apresentado na Tabela 9 como "terceiro caso", que vem a ser o plantio de mudas enxertadas adquiridas de viveiristas particulares.

Calculado o valor presente à taxa de desconto de $12 \%$ ao ano, chegou-se ao valor de Cr\$6.218.420. Tem-se, em seguida, o valor obtido para a formação da muda enxertada em viveiro propprio, com custos totais no valor de Cr\$ 6.032 .840 - o valor para a formação do porta-enxerto, que alcançou a ci fra de Cr\$5.979.200. 
Tabela 9 - Custo Mēdio Anualizado de Produção de Seringais Cultivados, por Hectare, sob Diferentes Taxas de Desconto, para Três Sistemas de Produção, Região de São José do Rio Preto, Estado de São Paulo (em mil cruzeiros de Maio de 1985).

\begin{tabular}{|c|c|c|c|c|c|c|c|c|}
\hline \multirow{2}{*}{$\begin{array}{l}\text { Sistema de } \\
\text { produção }\end{array}$} & \multicolumn{2}{|l|}{$6 \%$} & \multicolumn{2}{|l|}{$10 \%$} & \multicolumn{2}{|l|}{$12 \%$} & \multicolumn{2}{|l|}{$20 \%$} \\
\hline & $\begin{array}{l}\text { Valor presente } \\
\text { anualizado }\end{array}$ & $\%$ & $\begin{array}{l}\text { Valor presente } \\
\text { anual izado }\end{array}$ & $\%$ & $\begin{array}{l}\text { Valor present } \\
\text { anualizado }\end{array}$ & te $\%$ & $\begin{array}{l}\text { Valor presente } \\
\text { anualizado }\end{array}$ & $\%$ \\
\hline 19 Caso & & & & & & & & \\
\hline $\begin{array}{l}\text { Formação de Porta- } \\
\text { enxerto em viveiro } \\
\text { pröprio } \\
\text { 1.1. Custo variävel } \\
\text { 1.2. Custo fixo }\end{array}$ & $\begin{array}{l}2.786,17 \\
1.807,70\end{array}$ & $\begin{array}{l}61 \\
39\end{array}$ & $\begin{array}{l}3.071,76 \\
2.382,33\end{array}$ & $\begin{array}{l}56 \\
44\end{array}$ & $\begin{array}{l}3.242,81 \\
2.736,39\end{array}$ & $\begin{array}{l}54 \\
46\end{array}$ & $\begin{array}{l}4.156,45 \\
4.684,56\end{array}$ & $\begin{array}{l}47 \\
53\end{array}$ \\
\hline Total & $4.593,87$ & 100 & $5.454,10$ & 100 & $5.979,20$ & 100 & $8.841,02$ & 100 \\
\hline 20 Caso & & & & & & & & \\
\hline $\begin{array}{l}\text { Formação de mudas } \\
\text { enxertadas } \\
\text { 2.1. Custo variävel } \\
\text { 2.2. Custo fixo }\end{array}$ & $\begin{array}{l}2.812,02 \\
1.807,70\end{array}$ & $\begin{array}{l}61 \\
39\end{array}$ & $\begin{array}{l}3.114,48 \\
2.382,33\end{array}$ & $\begin{array}{l}57 \\
43\end{array}$ & $\begin{array}{r}3.296,45 \\
2.736,39\end{array}$ & $\begin{array}{l}55 \\
45\end{array}$ & $\begin{array}{l}4.274,38 \\
4.684,56\end{array}$ & $\begin{array}{l}48 \\
52\end{array}$ \\
\hline Total & 4.619 .73 & 100 & $5.496,82$ & 100 & $6.032,84$ & 100 & $8.958,94$ & 100 \\
\hline $\begin{array}{l}\frac{39}{\text { Aquisição de mudas }} \\
\text { enxertadas }\end{array}$ & & & & & & & & \\
\hline $\begin{array}{l}\text { 3.1. Custo variävel } \\
\text { 3.2. Custo fixo }\end{array}$ & $\begin{array}{l}2.892,28 \\
1.807,70\end{array}$ & $\begin{array}{l}62 \\
38\end{array}$ & $\begin{array}{l}3.258,20 \\
2.382,33\end{array}$ & $\begin{array}{l}58 \\
42\end{array}$ & $\begin{array}{l}3.482,03 \\
2.736,39\end{array}$ & $\begin{array}{l}56 \\
44\end{array}$ & $\begin{array}{l}4.710,89 \\
4.684,56\end{array}$ & $\begin{array}{l}50 \\
50\end{array}$ \\
\hline Total & $4.699,98$ & 100 & $5.640,53$ & 100 & $6.218,42$ & 100 & $9.395,46$ & 100 \\
\hline
\end{tabular}


A Tabela 9 mostra, ainda, as participações dos custos variáveis e fixos calculados às diferentes taxas de desconto. No primeiro caso, o custo variável tem uma participação, no custo total, que varia de $61 \%$, à taxa de $6 \%$, até $47 \%$, à taxa de $20 \%$ ao ano.

Para o segundo caso, essas participações não diferem muito do que foi observado no caso anterior. No terceiro caso, a participação do custo variável è de $62 \%$, à taxa de $6 \%$ ao ano, e de $50 \%$ à taxa de $20 \%$ ao ano.

Os itens de maior peso que compõem os custos variāveis tanto no sistema de formação de porta-enxerto como no de formação da muda, ambos em viveiro próprio, são os gastos com mão-de-obra e insumos, podendo-se afirmar que praticamente se equivalem. No caso de compra de muda formada, o custo variável é mais oneroso devido ao desembolso exigido para adquiri-las.

Os custos fixos são constantes em qualquer sís tema variando, apenas, de acordo com as taxas de desconto.

Dentre os itens que compõem os custos fixos, o mais representativo refere-se à remuneração da terra.

Esta constatação assim como as referentes aos custos variáveis são observadas analisando os dados que constam das Tabelas 29,30 e 31 do Apêndice 2.

Pelas referidas tabelas, nota-se que as diferenças nos custos variäveis dos três sistemas de produção con centram-se no primeiro ano de implantação do seringal. A par- 
tir do segundo ano há uma equivalência entre eles. Do segundo ao quinto ano tem-se, apenas, tratos culturais, porém, a partir do sexto tem-se, alēm de alguns tratos, a operação de "sangria". Nesta fase, os custos variáveis são, praticamen te, representados pelo desembolso para remunerar a mão-de-obra, evidenciando uma atividade cuja tecnologia caracteriza-se por trabalho intensivo.

A Tabela:lo mostra os custos médios anualizados de produção de lätex, para três níveis de produtividade por hectare na região de São José do Rio Preto.

Considerando o critério básico utilizado neste trabalho em que o custo de oportunidade do capital próprio é de $12 \%$ ao ano, obteve-se os menores custos, por litro de látex, para o sistema de produção de formação do porta - enxerto ou "cavalo". Os valores obtidos foram os seguintes: Cr\$ 2.420 , Cr\$1.930 e Cr\$1.440, respectivamente, para os niveis de pro dutividade considerados como "mínimo", "médio" e "máximo". 0 nivel "mínimo", como já foi comentado, representa a produtivi dade dos seringais adultos da região de São José do Rio Preto, cujos dados de produção acusaram $2.800 \mathrm{litros/ha/ano.} \mathrm{Em}$ se tratando de dados mëdios, hà produtores que estão conseguindo tanto produtividades abaixo da média como produtores que estão alcançando níveis superiores. Estes ültimos estão maximizando a produção e, consequlentemente, obtendo maior lucratividade. 
Tabela 10 - Custo Médio Anualizado de Produção, por litro de lätex, para Três Niveis de Produtividade por hectare, em Três Sistemas de Produção, Região de São José do Rio Preto, Estado de São Paulo (em mil cruzeiros de Maio de 1985).

\begin{tabular}{|c|c|c|c|c|c|}
\hline & & $6 \%$ & $10 \%$ & $12 \%$ & $20 \%$ \\
\hline $\begin{array}{l}\text { Sistema de } \\
\text { produção }\end{array}$ & $\begin{array}{l}\text { Nivel de } \\
\text { produtividade }\end{array}$ & $\begin{array}{c}\text { Valor presente } \\
\text { anualizado }\end{array}$ & $\begin{array}{c}\text { Valor presente } \\
\text { anualizado }\end{array}$ & $\begin{array}{c}\text { Valor presente } \\
\text { anualizado }\end{array}$ & $\begin{array}{c}\text { Valor presente } \\
\text { anualizado }\end{array}$ \\
\hline \multicolumn{6}{|l|}{$1:$ Caso } \\
\hline Formação de porta- & Minimo & 1,81 & 2,18 & 2,42 & 3,72 \\
\hline enxero em viveiro & Mëdio & 1,45 & 1,75 & 1,93 & 2,98 \\
\hline prōprio & Mäximo & 1,08 & 1,30 & 1,44 & 2,22 \\
\hline $2:$ Caso & Mínimo & 1,82 & 2,20 & 2,44 & 3,77 \\
\hline Formaçã̃o de mudas & Mëdio & 1,46 & 1,76 & 1,95 & 3,02 \\
\hline enxertadas & Māximo & 1,09 & 1,31 & 1,45 & 2,25 \\
\hline 3: Caso & Minimo & 1,86 & 2,26 & 2,51 & 3,96 \\
\hline Aquisição de mudas & Médio & 1,48 & 1,81 & 2,01 & 3,16 \\
\hline enxertadas & Mäximo & 1,11 & 1,35 & 1,50 & 2,36 \\
\hline
\end{tabular}


Analisando os custos mëdios por litro de látex, para as duas regiões estudadas, observa-se que os custos unitārios conseguidos para a região de Sãó José do Rio Preto, em qualquer dos sistemas de produção, são superiores aos custos unitários obtidos no Vale do Ribeira, em que pese níveis de produtividade superiores. Esta constatação pode ser explicada pelo fator de se ter, em São José do Rio Preto, custos mëdios por hectare mais elevados, devido a maior participação dos custos fixos.

Assim sendo, calculou-se os custos unitários considerando somente as despesas operacionais; os resultados são mostrados nas Tabelas 11 e 12 .

Analisando os resultados observa-se que, ao ado tar essa metodologia, os custos unitärios para o Vale do Ribeira, calculados à taxa de $12 \%$, são superiores aos custos unitärios da região de São Josê do Rio Preto.

Em termos de custos mëdios de produção, a dife rença entre uma regĩão e outra consiste nos itens que compõem os custos fixos, principalmente remuneração à terra e o inves timento em maquinarias.

o preço médio da terra nua na região de são José do Rio Preto chega a ser 3,7 vezes maior do que o preço médio observado no Vale do Ribeira; o item máquinas e equipa mentos onera, apenas, os custos de Rio Preto, dado que no Vale do Ribeira a cultura é conduzida manualmente. Ainda, quanto ao preço da terra, este item pode estar superestimando os 
Tabela 11 - Custo Operacional Mēdio Anualizado de Produção, por litro de látex, para Três Níveis de Prodú tividade por Hectare, em Dois Sistemas de Produção, Região do Vale do Ribeira, Estado de São Paulo (em mil cruzeiros de Maio de 1985).

\begin{tabular}{|c|c|c|c|c|c|}
\hline & & $6 \%$ & $10 \%$ & $12 \%$ & $20 \%$ \\
\hline produção & produtividade & $\begin{array}{c}\text { Valor presente } \\
\text { anualizado }\end{array}$ & $\begin{array}{c}\text { Valor presente } \\
\text { anualizado }\end{array}$ & $\begin{array}{c}\text { Valor presente } \\
\text { anual izado }\end{array}$ & $\begin{array}{c}\text { Valor presente } \\
\text { anualizado }\end{array}$ \\
\hline \multicolumn{6}{|l|}{$1 \%$ Caso } \\
\hline Aquisição de & Mínimo & 1,41 & 1,60 & 1,72 & 2,41 \\
\hline muda & Mēdio & 1,13 & 1,29 & 1,38 & 1,93 \\
\hline enxertada & Mäximo & 0,81 & 0,91 & 0,98 & 1,37 \\
\hline \multicolumn{6}{|l|}{$2:$ Caso } \\
\hline Muda enxertada & Mínimo & 1,39 & 1,56 & 1,67 & 2,27 \\
\hline em viveiro & Médio & 1,11 & 1,24 & 1,33 & 1,80 \\
\hline próprio & Mäximo & 0,79 & 0,89 & 0,95 & 1,29 \\
\hline
\end{tabular}


Tabela 12. Custo Operacional Médio Anualizado de Produção, por litro de látex, para Três Niveis de Produtividade por Hectare, em Três Sistemas de Produção, Região de São Josē do Rio Preto, Estado de São Paulo (em mil cruzeiros de Maio de 1985).

\begin{tabular}{|c|c|c|c|c|c|}
\hline & & $6 \%$ & $10 \%$ & $12 \%$ & $20 \%$ \\
\hline $\begin{array}{l}\text { Sistema de } \\
\text { produção }\end{array}$ & $\begin{array}{l}\text { Nivel de } \\
\text { produtividade }\end{array}$ & $\begin{array}{c}\text { Valor presente } \\
\text { anualizado }\end{array}$ & $\begin{array}{c}\text { Valor presente } \\
\text { anual izado }\end{array}$ & $\begin{array}{l}\text { Valor presente } \\
\text { anualizado }\end{array}$ & $\begin{array}{c}\text { Valor presente } \\
\text { anualizado }\end{array}$ \\
\hline \multicolumn{6}{|l|}{10 Caso } \\
\hline Formação de porta & Minimo & 1,10 & $1 ; 23$ & 1,31 & 1,76 \\
\hline enxerto em viveiro & Mēdio & 0,88 & 0,98 & 1,05 & 1,40 \\
\hline próprio & Mäximo & 0,66 & 0,73 & 0,78 & 1,05 \\
\hline $2:$ Caso & Minimo & 1,11 & 1,25 & 1,33 & 1,80 \\
\hline Formação de mudas & Mēdio & 0,89 & 1,00 & 1,07 & 1,44 \\
\hline enxertadas & Māximo & 0,66 & 0,74 & 0,80 & 1,07 \\
\hline 3: Caso & Mínimo & 1,14 & 1,30 & 1,41 & 1,98 \\
\hline Aquisição de mudas & Mëdio & 0,91 & 1,04 & 1,13 & 1,59 \\
\hline enxertadas & Māximo & 0,68 & 0,78 & 0,84 & 1,18 \\
\hline
\end{tabular}


custos fixos, pois enquanto que para os demais fatores os pre ços considerados foram os que vigoraram no mês de maio de 1985 , para a terra considerou-se os preços do mês de junho do mesmo ano, dado que o IEA coleta e divulga os preços referentes a esse mès (13).

A fim de se ter elementos que permitissem comparar os resultados obtidos neste trabalho com os resultados a que chegaram NEVES et alii (15), foi necessārio uniformizar as unidades de produção.

o critério adotado foi calcular a produtividade de borracha seca com base na produtividade corrigida de lä tex, à taxa de $12 \%$ ao ano.

Para ostado de São Paulo a relação látexl borracha seca è a seguinte:

- Litoral: para 1 litro de lätex tem-se $27,6 \%$ de borracha seca.

- Planalto: para l litro de látex tem-se $31,1 \%$ de borracha seca.

Esses dados foram usados por CORTEZ (11), com base em análise efetuada nos laboratörios da Indústria de Bor racha São Roque, SP.

Na Tabela 13 tem-se as relações equivalentes para o Vale do Ribeira e região de São José do Rio Preto. 
Tabela 13 - Produtividade, por ha/ano, de Borracha Seca Obtida da Conversão Lātex/Borracha Seca, em Três Niveis de Produtividade por Hectare, para as Regiões do Vale do Ribeira e São José do Rio Preto, Estado de São Paulo.

\begin{tabular}{|c|c|c|c|}
\hline Região & $\begin{array}{c}\text { Nível } \\
\text { de } \\
\text { produtividade }\end{array}$ & $\begin{array}{l}\text { l/lätex } 1 \\
\text { por } \\
\text { ha/ano }\end{array}$ & $\begin{array}{c}\text { kg/borracha } 1 \\
\text { seca/ha/ } \\
\text { ano }\end{array}$ \\
\hline \multirow{3}{*}{ Vale do Ribeira } & minimo & $1.768,93$ & 488 \\
\hline & mëdio & $2.211,36$ & 610 \\
\hline & māximo & $3.100,24$ & 856 \\
\hline \multirow{3}{*}{ São Josê do R.Preto } & minimo & $2.475,18$ & 770 \\
\hline & o médio & $3.094,86$ & 963 \\
\hline & māximo & $4.147,85$ & 1.290 \\
\hline
\end{tabular}

1 Corrigida à taxa de $12 \%$ a.a.

Fonte: Dados de pesquisa de campo.

Com este procedimento foi possivel montar as

Tabelas 14 e 15, que mostram os custos unitários de borracha seca para o Vale do Ribeira e São José do Rio Preto, calculados à taxa de $12 \%$ ao ano. 
Tabela 14 - Custo médio Anualizado de Produção, por Quilo de Borracha Seca, para Três Niveis de Produtividade por Hectare, em Dois Sistemas de Produção, Vale do Ribeira, Estado de São Paulo (em mil cruzeiros de Maio de 1985).

\begin{tabular}{lcc}
\hline $\begin{array}{l}\text { Sistema de } \\
\text { produçäo }\end{array}$ & $\begin{array}{c}\text { Produtividade } \\
(\mathrm{kg} / \mathrm{ha} / \mathrm{ano})\end{array}$ & $\begin{array}{c}\text { Valor presente } \\
\text { anualizado à taxa } \\
12 \% \text { a.a. }\end{array}$ \\
\hline 10: Caso & 488 & 7,18 \\
\hline Aquisição de muda & 610 & 5,74 \\
enxertada & 856 & 4,09 \\
2.: Caso & 488 & 6,92 \\
Mudas enxertadas & 610 & 5,53 \\
em viveiro pröprio & 856 & 3,94 \\
\hline Corrigida à taxa de $12 \%$ a.a. & &
\end{tabular}


Tabela 15 - Custo Mēdio Anualizado de Produção, por Quilo de Borracha Seca, para Três Niveis de Produtivi dade por Hectare, em Três Sistemas de Produção, São Josē do Rio Preto, Estado de São Paulo. (em mil cruzeiros de Maio de 1985).

\begin{tabular}{|c|c|c|c|}
\hline $\begin{array}{c}\text { Sistema de } \\
\text { produção }\end{array}$ & $\begin{array}{c}\text { Produtividade } \\
\text { (kg/ha/ano })\end{array}$ & $\begin{array}{l}\text { Valor Presente } \\
\text { anualizado } \\
\text { à taxa de } 12 \% \text { a.a. }\end{array}$ & $\cdots$ \\
\hline \multicolumn{4}{|l|}{19 Caso } \\
\hline Formação de porta- & 770 & 7,77 & \\
\hline enxerto em viveiro & 963 & 6,21 & \\
\hline prōprio & 1.290 & 4,63 & \\
\hline 29 Caso & 770 & 7,83 & \\
\hline Formação de muda & 963 & 6,26 & \\
\hline enxertada & 1.290 & 4,68 & \\
\hline 3: Caso & 770 & 8,10 & \\
\hline Aquisição de muda & 963 & 6,46 & \\
\hline enxertada & 1.290 & 4,82 & \\
\hline
\end{tabular}

1 Corrigida à taxa de $12 \%$ a.a. 
Para o Vale do Ribeira o custo mais baixo foi de Cr\$3.940 por quilo de borracha seca para seringais que, produzem, em média, 856 quilos de borracha por hectare/ano, no sistema de produção de formação de muda em viveiro próprio. Contudo, os seringais da região apresentaram, na época da pesquisa, uma produtividade que foi considerada neste trabalho como "minima" (equivalente a $488 \mathrm{~kg} / \mathrm{ha}$ ), no sistema de aquisição de muda, que è o mais usual. Nesse caso, o custo por quilo de borracha, alcançou o valor de cr $\$ 7.180$.

Seguindo o mesmo raciocínio, para a região de São José do Rio Preto o custo por quilo de borracha foi de Cr\$7.770. Entretanto, o mesmo sistema de produção (formação do porta-enxerto) com a produtividade considerada máxima, apre sentou um custo unitário de Cr\$4.630.

Considerando os custos unitärios que mais reproduzem as condições vigentes em cada região e convertendo-os em dólares ( 1 US $\$=5.223,87$, valor médio em maio de 1985) chega-se aos seguintes resultados: US\$1,37 por quilo para o Vale do Ribeira e US\$ 1,49 para a região de São José do Rio Preto. NEVES et alii (15) obtiveram US\$ 1,42 por quilo, como custo médio para o Estado de São Paulo, considerando uma produtividade de $1.223,6$ quilos por hectare, corrigida à taxa de desconto de $12 \%$ ao ano.

Tomando-se o custo por hectare obtido neste trabalho para a região de São José do Rio Preto (NEVES et alii, realizaram a pesquisa nessa região) e adotando o nível de 
produtividade igual a $1.223,6$ quilos por hectare, o custo unitärio chega a US\$0,93.

A fim de fornecer maiores informações aos produtores e tēcnicos envolvidos com a heveicultura em são Paulo adotou-se, para o caso em discussão, o mesmo procedimento quando foram calculados os custos por litro de látex, ou seja, além de calcular os custos totais médios foram calculados também, os custos operacionais, para efeito de comparação. 0 s resultados são mostrados nas Tabelas 16 e 17.

Para o Vale do Ribeira, o custo que era de Cr\$ 7.180 por quilo caiu para Cr\$6.240 e para São José do Rio Pre to, de cr\$7.770 caiu a cr\$4.210.

Fazendo-se a conversão para dôlar, tem-se para - Vale do Ribeira o valor de US\$1,19 por quilo e para São Josè do Rio Preto, US\$ 0,81 , à taxa de desconto de $1 \%$ ao áno. os custos médios anualizados de produção, por quilo de borracha seca (custo total e operacional) em cruzeiros e em dólares, para os sistemas de produção mais usuais nas regiões do Vale do Ribeira e São José do Rio Preto, em três níveis de produtividade por hectare/ano, são mostrados na Tá bela 18 .

Finalizando, a anälise dos resultados mostra que a borracha extraída de seringais adultos do Estado de São Paulo está sendo obtida a custos superiores ao preço vigente no mercado internacional que, de acordo com os dados fornecidos pelo Superintendente da SUDHEVEA, em abril de 
Tabela 16 - Custo Operacional Médio Anualizado de Produção, por Quilo de Borracha Seca, para Trēs níveis de Produtividade por Hectare, em Dois Sistemas de Produção, Vale do Ribeira, Estado de São Paulo (em mil cruzeiros de Maio de 1985).

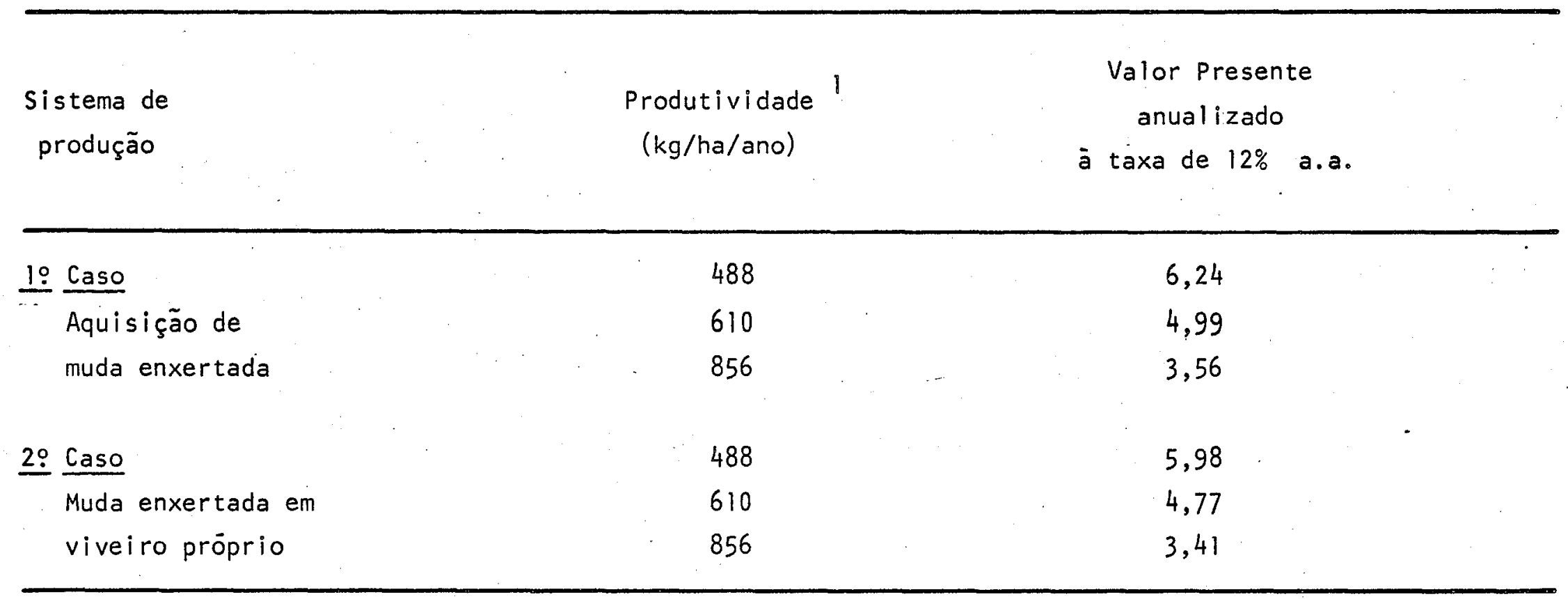

1 Corrigida à taxa de $12 \%$ a.a. 
Tabela 17 - Custo Operacional Médio Anualizado de Produção, por Quilo de Borracha Seca, para Três níveis de Produtividade por Hectare, em Três Sistemas de Produção, São José do Rio Preto, Estado de São Paulo (em mil cruzeiros de Maio de 1985).

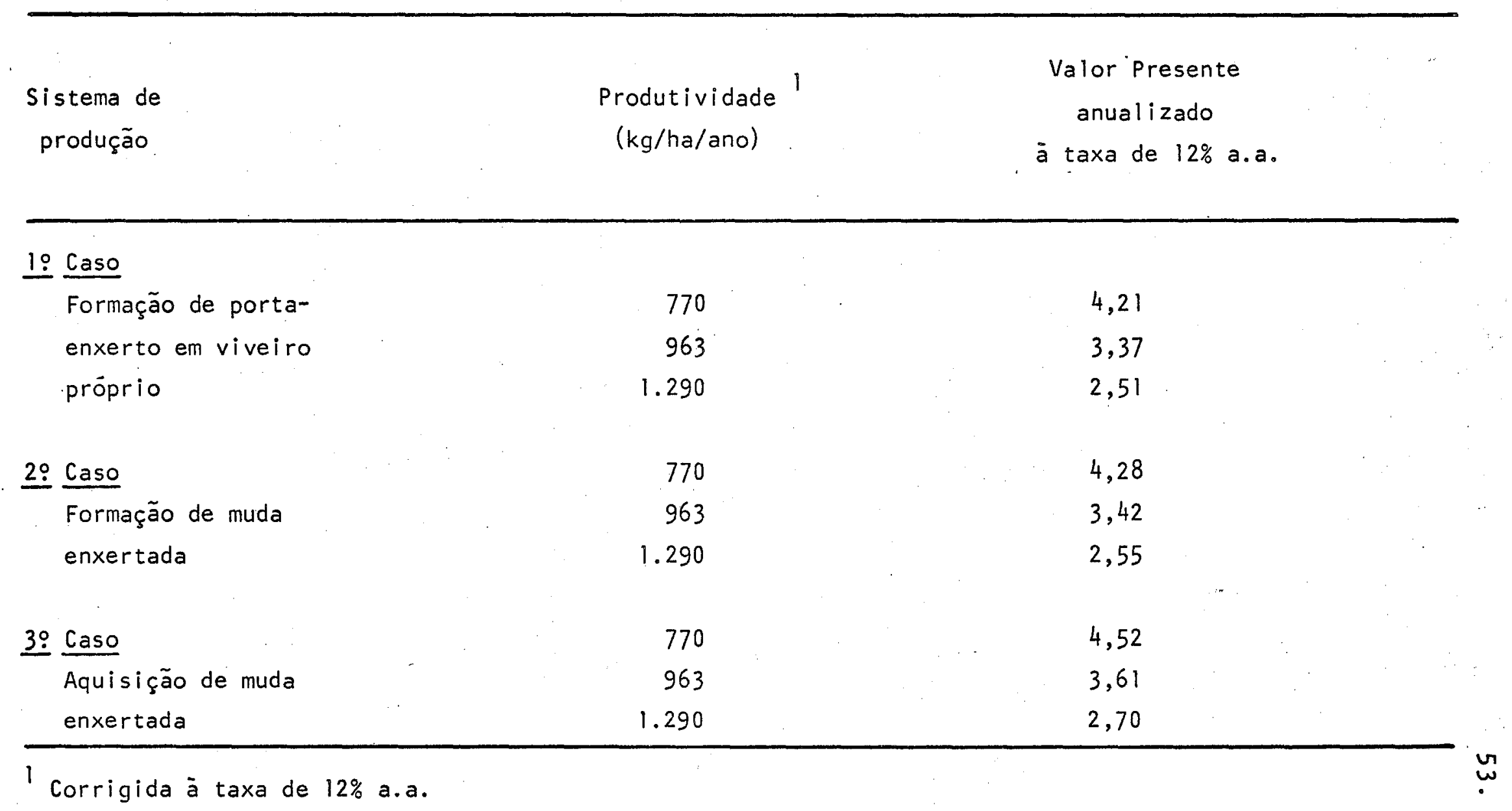


Tabela 18 - Custo Médio Anualizado de Produção, por Quilo de Borracha Seca, à Taxa de Desconto de 12\% aa, para os Sistemas de Produção mais Usuais nas Regiões do Vale do Ribeira e São Josẽ do Rio Pre to, Estado de São Paulo.

\begin{tabular}{|c|c|c|c|c|c|}
\hline \multirow{2}{*}{ Região } & \multirow{2}{*}{$\begin{array}{c}\text { Produtividade } \\
\text { (kg/ha/ano) }\end{array}$} & \multicolumn{2}{|c|}{ Custo Total } & \multicolumn{2}{|c|}{ Custo Operacional } \\
\hline & & $\operatorname{cr} \$ 1.000 / \mathrm{kg}$ & $U S \$ / \mathrm{kg}^{2}$ & $\mathrm{Cr} \$ 1.000 / \mathrm{kg}$ & $U S \$ / \mathrm{kg}^{2}$ \\
\hline VALE DO RIBEIRA & & & & $\ldots$ & \\
\hline (Aquisição de muda & 488 & 7,18 & 1,37 & 6,24 & $1,19^{\circ}$ \\
\hline formada) & 610 & 5,74 & 1,10 & 4,99 & 0,95 \\
\hline SÃO JOSE DO RIO PRETO & 856 & 4,09 & 0,78 & 3,56 & 0,68 \\
\hline (formação de porta- & 770 & 7,77 & 1,49 & 4,21 & 0,81 \\
\hline \multirow[t]{2}{*}{ enxerto) } & 963 & 6,21 & 1,19 & 3,37 & 0,65 \\
\hline & 1.290 & 4,63 & 0,89 & 2,51 & 0,48 \\
\hline
\end{tabular}

1 Corrigidas à taxa de $12 \%$ a.a.

2 US\$ $=\operatorname{Cr} \$ 5.223,87$, valor médio em Maio de 1985. 
1986, estava em torno de US\$ $0,75 / \mathrm{kg}$, enquanto o preço médio em vigor no mercado interno, na mesma época, era US\$ $2,3 / \mathrm{kg}$. A este preço, os produtores paulistas estão tendo um ganho real superior ao dos produtores das regioes tradicionais no cultivo da hevea, pois o Conselho Nacional da Borracha, ao fi xar os preços dos diversos tipos de borracha natural, leva em conta, entre outros fatores, o custo de produção da região Amazónica. De acordo com NEVES et alii (15) os custos mais elevados de produção são de seringais dos Estados do Amazonas e Parà. 


\section{CONCLUSÃO}

Os custos foram calculados com base nas matrizes de coeficientes técnicos representativas dos sistemas de produção em uso em duas regiões distintas do Estado de São Pau lo: região litorânea e planalto paulista.

A primeira compreendeu o Vale do Ribeira e a segunda, a região de São José do Rio Preto, sendo, ambas, as mais tradicionais em relação à heveicultura. Para cada região foram considerados três niveis de produtividade por hectare, para efeito de comparação dos custos unitários.

A análise dos resultados permite tirar uma série de conclusões sobre os resultados obtidos por hectare e por unidade produzida.

Quando os custos foram calculados por hectare, à taxa de $12 \%$ ao ano, em cruzeiros do mês de maio de 1985 , - custo mais baixo foi obtido para os seringais do Vale do Ri beira, para o sistema de formação de mudas em viveiro pró- 
prio; o valor correspondente foi de Cr\$3.376.830. Entretanto, o sistema de produção mais usual na região é caracteriza do pela compra da muda de viveirista particular. Nesse caso, - custo obtido por hectare foi de Cr\$3.502.240.

Para a região de São José do Rio Ṕreto, o custo mais baixo foi obtido para o sistema de produção de formação do porta-enxerto em viveiro localizado na propriedade e com enxertia no campo, sendo este, o sistema mais em uso por ocasião do levantamento dos dados. 0 custo médio obtido por hectare foi de Cr\$5.979.200. Para o sistema de formação de muda, o custo foi de $\operatorname{cr} \$ 6.032 .840$ e no caso de o produtor ad quirir a muda, o custo alcançou o valor de Cr\$6.218.420.

os custos médios mais elevados para a região de São Josè do Rio Preto são devidos às diferenças nas remunerações de fatores do custo fixo.

Os custos médios por unidade produzida foram calculados por litro de látex e por quilo de borracha seca, apös proceder-se a conversäo lätex/borracha seca. Para o Vale do Ribeira as anälises acusam $27,6 \%$ de borracha seca por litro de látex e para o planalto, $31,1 \%$.

Os custos unitärios por litro de látex calculados à taxa de $12 \%$ ao ano, a preços de maio de 1985 , apresen taram para o Vale do Ribeira valores inferiores aos obtidos para São José do Rio Preto.

Para o sistema de produção de aquisição de muda, o mais usado pelos produtores locais, os custos variaram 
de C.r\$1.130 por litro, para a produtividade considerada "máxima", até cr\$1.980 por litro, para a produtividade "minima". Este nivel mínimo vem a ser a produtividade média obti da de seringais da região que estão com idade que varia de 20 a 25 anos.

Para o sistema de produção em que o produtor forma a própria muda os custos unitärios são inferiores. Dependendo do nivel de produtividade os custos variaram de Cr\$1.090 até Cr\$1.930, por litro de látex.

Em termos de borracha seca, o custo médio por unidade, para o sistema mais usual e para a produtividade equi valente a $488 \mathrm{~kg} / \mathrm{ha} / \mathrm{ano}$, apresentou o valor de $\mathrm{Cr} \$ 7.180$ por quilo.

Na região de São José do Rio Preto, os custos mëdios, por litro de látex, para o sistema de produção de for mação do porta-enxerto foram os mais baixos, variando de Cr\$1.440 até cr\$2.420 por litro, conforme a produtividade considerada por hectare/ano. Este ültimo valor é o que está sendo conseguido pela maioria dos produtores, dado que corresponde à produtividade média da região.

Calculado o custo por quilo de borracha seca, para o mesmo sistema de produção e o mesmo nivel de produtivi dade obteve-se o valor de cr $\$ 7.770$.

0s custos por hectare e por unidade produzida foram calculados, também, considerando taxas de desconto de $6 \%, 10 \%$ e $20 \%$ ao ano, com o objetivo de fornecer 
informações mais seguras aos produtores na tomada de decisão.

Para comparar os custos de produção por quilo de borracha seca obtidos neste trabalho com os custos a que chegaram NEVES et ali i (15) fez-se a conversão em dōlares, con siderando o valor médio do dólar em maio de 1985.

Para o Vale do Ribeira, o custo unitärio para o. sistema de produção' mais representativo foi de US\$ 1,37 e para a região de São José do Rio preto obteve-se um custo de US\$1,49. NEVES et ali (15) obtiveram um custo unitário para o Estado de São Paulo de US\$1,42, utilizando a mes ma metodologia. A diferença nos resultados consiste, basicamente, nas produtividades que foram consideradas nos dois tra balhos.

Comparando os custos de produção por unidade com o preço vigente no mercado interno conclui-se que os produtores estão obtendo gántios reais. Esta situação deverá per sistir enquanto o Governo Federal subsidiar o preço internamente, como incentivo à expansão da heveicultura, à fim de o País conseguir a auto-suficiência em borracha natural num período o mais curto possível. Porém, a perspectiva quanto ao mercado futuro da borracha natural é ainda incerta e, sendo assim, è de fundamental importância que os produtores interes sados em investir na seringueira estejam conscientes de que a atual euforia, pelos retornos que a borracha vem proporcionando, não deverá continuar por tempo indeterminado. Se os 
programas de incentivo à produção de borracha surtirem os efei tos esperados pelas autoridades governamentais, a tendência é haver uma equalização do preço interno com o préço do mercado internacional, que está em torno de US\$ 0,75 por quilo. 


\section{LITERATURA CITADA}

1. ARRUDA, Silvía T. A cultura da seringueira em São Paulo: viabilidade económica. São Paulo, Secretaria de Agricultura e Abastecimento, Instituto de Economia Agríco la, 1985. 33p. (Relatório de Pesquisa, 6/85).

2. BERNARDES, M.S.; SANTOS, G.G. dos; SIQUEIRA, R.S. Beneficiamento, mercado e politica da borracha natural. In: SIMPÓSIO SOBRE A CULTURA DA SERINGUEIRA NO ESTADO DE SÃo PAULO, 1., Piracicaba, 1986. Campinas, Fundação Cargi11, 1986. Cap. 18, p.317-333.

3. BORREAN1, 0.P. et alii. Projeção da demanda de al astômeros para o período 1985-90. Salvador. Resumos do Tra balho. Anais do IV Seminário Nacional de Seringueira. p.116-117, citado por NEVES, E.M. Anälise Econômica do investimento em condiçōes de risco na cultura da borracha. Piracicaba, ESALQ/USP, 1984. P. 12.

4. BRASIL. Superintendência da Borracha (SUDHEVEA-MIC). Anuário Estatistico, mercado estrangeiro, 1982. Brasília, 1983. 
5. BRASIL. Superintendência da Borracha (SUDHEVEA-MIC). Re la törio de Atividades/1982. Brasilia, 1983. 58p.

6. BRASIL. Superintendência da Borracha (SUDHEVEA-MIC). Relatörio de Atividades/1983. Brasilia, 1984. 64 p.

7. BRASIL. Superintendência da Borracha (SUDHEVEA-MIC). Relatörio de Atividades/1984. Brasília, 1985 (no prelo).

8. CAMARGo, Angelo P. de: Possibilidades climáticas da cultura da seringueira em São Paulo. 2.ed. Campinas, Secretaria da Agricultura, Instituto Agronómico, 1963. 23p. (Boletim 110).

9. CARDOSO, Mário. Subsídios ao desenvolvimento da heveicul tura no Estado de São Paulo. Campinas, Secretaria da Agricultura, Instituto Agronômico, 1979. 78p. (mimeografado).

10. CASTRO, A.M.G. de et alii. Projeção da produção da borra cha natural no Brasil: 1985 a 2000. Salvador. Resumo dos Trabalhos nos Anais do IV Seminário Nacional da Seringueira. p. 120-121, citado por NEVES, E.M. Análise econômica do investimento em condições de risco na cultura da borracha. Piracicaba, ESALQ/USP, 1984. p. 12 .

11. CORTEZ, Jayme V. Histörico e expansão da cultura da seringueira no Estado de São Paulo. In: SIMPOSIO SOBRE A CULTURA dA SERINGUEIRA EM SÃO PAULO, 1., Piracicaba, 1986. Campinas, Fundação Cargil1, 1986. Cap. 1, P.1-9. 
12. GRILLI, Enzo R.; AGOSTINI, B.B.; WeLVAARS; M.H. A economia mundial da borracha: estruturas, mudanças e perspectivas. Washington, World Bank/FA0, 1978. 63p. (Re latório de Grupo de Trabalho, trad. desconhecida).

13. INFORMAÇOES ECONÔMICAS. São Paulo, Secretaria de Agricul tura e Abastecimento, IEA, v.15, n.9, set. 1985.

14. NEVES, Evaristo M. Anālise econômica do investimento em condiçoes de risco na cultura da borracha. Piracicaba, ESALQ/USP, 1984. 171p. (Tese de Livre-Docência).

15. NEVES, Evaristo M. et alii Custo de produção de borracha natural em seringais cultivados. Piracicaba, Fundação de Estudos Agrários Luiz de Queiroz, 1983. $84 p$. (Relatório de Pesquisa).

16. ORTOLANI, A.A. et alii. Aptidão agroclimática para regio nalização da heveicultura no Brasil. In: SEMINARIO BRA SILEIRO PARA RECOMENDAÇOES DE CLONES DE SERINGUEIRA, I, Brasilia, 1983. Anais... Brasília, EMBRAPA - SUDHEVEA, 1983. P. 19-28.

17. PINTO, Nelson P.A. Politica da borracha no Brasil: a falência da borracha vegetal. São Paulo, Ed. Hucitec/ Conselho Regional de Economia, 1984. 168p. (Economia e Planejamento: Série teses e pesquisas).

18. POLHAMUS, J.P. Rubber, botany, production and utilization. New York, Interscience Publ., 1962, citado por VIRGENS \& CASTRO. In: SIMPOSIO SOBRE A CULTURA DA SERINGUEIRA NO ESTAdO DE SÃo PAULO, 1., Piracicaba, 1986. p.274. 
19. PRO-BORRACHA: Programa Estadual de Borracha Natural. São Paulo, Secretaria de Agricultura e Abastecimento, 1981. 37p. (Relatörio de Grupo de Trabalho).

20. PROGRAMA de incentivo à produção da borracha natural: 11 . Diário Oficial da União, 14 de outubro de 1977. p. $14044-14045$.

21. REIS, Arthur C.F. 0 seringal e o seringueiro. Rio de Janeiro, Ministério da Agricultura, Serviço de Infor mação Agrícola, 1953. p.160, citado por PINTO, N.P.A.. Politica da borracha no Brasil. São Paulo, Hucitec, 1984. P.21.

22. ROSOLEN, José E. E RAMOS, Paulo S. Manual de procedimen to para atualização das estimativas de custo operacio nal das principais atividades agropecuärias do Estado de São Paulo. São Paulo, Secretaria da Agricultura, Instituto de Economia Agrícola, 1975. 11p. (Relatório de Pesquisa, 2/79).

23. SÃo PAULO. Secretaria de Economia e Planejamento. Departamento de Estatística. Conheça seu municipio: Região do Vale do Ribeira. São Paulo, 1974. v.l.

24. SÃO PAULO. Secretaria de Economia e Planejamento. Departamento de Estatística. Diagnöstico: 8ạ Região do Vale do Ribeira. São Paulo, 1972. v.8.

25. SIMPOSIO SOBRE A CULTURA DA SERINGUEIRA NO ESTADO dE SÃO PAULO, 1., Piracicaba, 1986. Campinas, Fundação Cargill, 1986. (Palestra de Encerramento) S.n.t. 
26. VIRGENS Fo, A.C. E CASTRO, P.R.C. Sangria da seringueira (Hevea spp). In: SIMPOSIO SOBRE A CULTURA DA SERIN GUEIRA NO ESTADO DE SÃO PAULO, l., Piracicaba, 1986. Campinas, Fundação Cargi11, 1986. cap. 17. p. 271-315. 


\section{APÊNDICE 1}

- ASPECTOS DA HEVEICULTURA NO MUNDO E NO BRASIL

- A Heveicultura no Mundo

A partir do final da II Grande Guerra Mundial atë 1973, a economia mundial da borracha teve um crescimento bastante räpido, como consequência da evolução tecnológica observada nas ültimas décadas e que provocaram profundas mudanças estruturais no mercado da borracha.

As borrachas sintéticas, desenvolvidas a partir das necessidades dos tempos de gerra, passaram a ser produzidas em escala cada vez maior, deslocando a posição desfrutada pela borracha natural na primeira metade do século. produção de elastómeros sintéticos tornou-se bastante diversificada, tanto em termos de tipos, como localização geogräfi ca e performance de produtos. 
Conforme estudos de GRILLI et alii (12), o cres cimento rápido da tecnologia na Europa ocidental e Japão e a contínua expansão da produção automobilística na Amērica do Norte fizeram com que a demanda por elastómeros crescesse a uma taxa média anual de $6 \%$, aproximadamente, no período de 1948/1973: Contudo, em 1973 a economia mundial da borracha sofreu o seu primeiro grande golpe, provocado pela crise do petróleo e a subsequlente quadruplicação dos preços do óleo cru (o barril passou de US\$3 a 12). Para uma indústria cujo maior componente (borracha sintētica) depende tão pesadamente de estoques de derivados do petróleo, a sübita e drástica elevação dos preços do öleo cru, que se vérificou em 1973/74, representou uma mudança de grandes proporções, tanto ná estrü tura de custos como na produção.

o outro componente (borracha natural), embora menos afetado do que a borracha sintética, sofreu os efeitos indiretos da crise do petröleo, quais sejam: aceleração da in flação mundial, mudanças no comportamento dos consumidores e dúvidas quanto à demanda mundial futura de elastómeros no se tor automobilístico. Essas düvidas foram logo confirmadas com a sēria recessão econômica que afetou os países industrializa dos em 1974/75, provocando uma queda drástica na produção industrial em geral, inclusive na indústria automobilística. os investimentos no setor da borracha sintētica tiveram, virtual mente, uma parada.

os projetos industriais que apareceram nesse 
68.

período mostram, claramente, o ponto de vista pessimista que Ihes serviu de base em termos de crescimento futuro, a longo prazo, da demanda de elastómeros, por exemplo: vef́culos meno res e mais leves, baixa intensidade no uso de transportes individuais e a rāpida evolução no mercado mundial de pneus radiais de longa duração.

A demanda a longo prazo dos elastómeros,

a partir de 1973, também foi examinada com detalhes por GRILLI et alii (12). A projeção mostrou que as mudanças tecnológicas, provavelmente, retardariam o crescimento futuro da deman da mundial e que esta deveria crescer a uma razão média de $5 \%$ a 5,5\% a.a., entre 1976 e 1990, aquëm das taxas históricas ob servadas.

Comparando as taxas estimadas pelos autores com - crescimento real que ocorreu após esse ano, concluimse que os resultados esperados de $5 \%$ a $5,5 \%$ a.a. foram até otimistas, levañdo em consideração que partiram da pressuposição de preços constantes do óleo cru a partir de 1977.

Os dados apresentados pela SUDHEVEA (5), sobre a evolução do consumo mundial de borracha no período $1975 / 82$, revelam que houve um crescimento real, porém, oscilátorio, da do o segundo impacto sofrido pela economia mundial em 1979, quando o preço do petróleo atingiu US\$34 o barril.

A evolução do consumo mundial de borracha natú ral e sintética é mostrada na Tabela 19. Embora os dados referentes a.1985 sejam dados parciais, até o mês de setembro, 
Tabela 19 - Evolução do Consumo Mundial de Borracha no Periodo 1975/85 (em 1.000 t/peso seco).

\begin{tabular}{llll}
\hline & Borracha & Borracha & Total \\
Ano & natural & sintëtica & \\
& & & \\
\hline 1975 & 3.368 & 7.028 & 10.396 \\
1976 & 3.505 & 7.915 & 11.420 \\
1977 & 3.715 & 8.420 & 12.135 \\
1978 & 3.725 & 8.770 & 12.495 \\
1979 & 3.870 & 9.125 & 12.995 \\
1980 & 3.760 & 8.685 & 12.445 \\
1981 & 3.700 & 8.465 & 12.165 \\
1982 & 3.655 & 8.005 & 11.660 \\
1983 & 3.985 & 8.385 & 12.370 \\
1984 & 4.024 & 8.975 & 12.999 \\
$1985^{*}$ & 4.032 & 9.075 & 13.107 \\
\hline
\end{tabular}

* Dados até setembro

Fonte: SUDHEVEA ( 5 e 7$)$. 
os resultados já revelam uma reativação no mercado de elastómeros, assim como, em toda a economia mundial, em consequência da contínua queda no preço do petróleo ocorrida no início de 1983. O Relatório Anual da "International Natural Rubber organization (INRO)" citado pela SUDHEVEA (6) afirma que o consumo de borracha natural nos principais paises consumidores, nos seis primeiros meses de 1983, cresceumais de $5 \%$ em relação ao mesmo período de 1982 afirmando ainda que: "se con siderar uma perspectiva mais favorável para os ültimos meses do ano, é provável que o consumo de borracha natural atinja, em 1983, niveis bem maiores do que os baixos niveis alcançados em 1982". Na realidade o consumo teve um aumento real de $6 \%$, em relação a 1982 .

Em termos de produção mundial de borrachas, o comportamento foi semelhante (Tabela 20) e é de se esperar que a oferta cresça alinhada com as necessidades de mercado. Entretanto, segundo GRILLI et ali $\mathbf{i}$ (12), com base em informaçōes correntes a respeito de äreas com seringais, poderá ocor rer um "deficit" na demanda potencial de borracha natural da ordem de meio milhão de toneladas e se esse "deficit". não for satisfeito atravēs de aumento de produção de borracha natural, será, provavelmente, preenchido pelos elastómeros sin téticos.

Contudo, a fim de que o aumento na oferta de borracha natural se concretize, decisões de novos investimen tos terão que ser tomadas, de imediato, pelos países produtores. 
Tabela 20 - Evolução da Produção Mundial de Borrachas no Periodo 1975/85 (em $1.000 \mathrm{t} /$ peso seco).

\begin{tabular}{llll}
\hline & Borracha & Borracha & Total \\
Ano & natural & sintética & 10.165 \\
\hline 1975 & 3.315 & 6.850 & 11.605 \\
1976 & 3.585 & 8.020 & 12.225 \\
1977 & 3.615 & 8.610 & 12.380 \\
1978 & 3.475 & 8.905 & 13.190 \\
1979 & 3.860 & 9.330 & 12.490 \\
1980 & 3.845 & 8.645 & 12.180 \\
1981 & 3.690 & 8.490 & 11.585 \\
1982 & 3.755 & 7.830 & 12.325 \\
1983 & 4.025 & 8.300 & 13.150 \\
1984 & 4.060 & 9.090 & 13.395 \\
$1985^{*}$ & 4.315 & 9.080 & \\
\hline
\end{tabular}

* Dados até setembro

Fonte: SUDHEVEA ( 5 e 7$)$. 
A diversificação geogräfica das fontes de ofer ta seria também uma vantagem adicional. Dados de produção mundial de borracha natural indicam que $80 \%$ da produção total pro vém do Sudeste Asiātico. Dentre os produtores asiáticos, a Malásia detém a supremacia, seguida pela Indonésia e Tailàndia. Entretanto, sabe-se que a Malásia vem reduzindo sua pro dução desde 1976, quando foi responsāvel por $45 \%$ da produção mundial (Tabela 21 ).

A par do que vem ocorrendo na Malásia, quando se propõe a diversificação geográfica da produção há que se pensar que o Sudeste Asiático é uma região politicamente instável. "o fechamento, por quaisquer circunstâncias, das exportações de borracha natural por parte da Asia, por certo deixaria o mundo ocidental em sérias dificuldades",

CARDOSO (9).

Tal fato parece revestir-se de grande importância para o Brasil, uma vez que, o país dispõe da maior área do mundo para o plantio da seringueira.

\section{- A Heveicultura no Brasil}

"A primeira metade do século XIX encontrou uma Amazônia praticamente habitada com uma economia próxima do ní vel da simples subsistência. O breve surto de prosperidade que marcou a segunda metade do século XVIII, sob os auspëcios da Companhia Geral do Gräo-Parā e Maranhão (1755-1758), foi 
Tabela 21 - Produção de Borrachas Naturais nos Principais Países e Brasil, 1972/81 (em 1.000 t/peso seco)

\begin{tabular}{lllllll}
\hline Ano & Malásia & Indonésia & Tailândia & Brasil & Outros (*) & Total \\
\hline 1972 & $1.304,1$ & 773,7 & 336,9 & 25,8 & 679,5 & $3.120,0$ \\
1973 & $1.542,3$ & 885,8 & 390,0 & 23,4 & $663,5$. & $3.505,0$ \\
1974 & $1.524,7$ & 855,0 & 379,5 & 18,6 & 667,3 & $3.445,1$ \\
1975 & $1.459,3$ & 822,5 & 355,0 & 19,3 & 658,8 & $3.314,9$ \\
1976 & $1.612,4 * *$ & 847,5 & 411,9 & 20,3 & 682,9 & $3.575,0$ \\
1977 & $1.588,0$ & 835,0 & 430,9 & 22,6 & 728,6 & $3.605,1$ \\
1978 & $1.583,0$ & 902,5 & 467,0 & 23,7 & 778,8 & $3.755,0$ \\
1979 & $1.569,1$ & 905,0 & 531,2 & 25,0 & 829,7 & $3.860,0$ \\
1980 & $1.552,2$ & $1.020,0$ & 501,1 & 27,8 & 713,8 & $3.815,0$ \\
1981 & $1.527,6$ & 855,0 & 495,0 & 30,3 & 712,1 & $3.620,0$ \\
\hline
\end{tabular}

(*) Sri-Lanka, Vietnan, Repüblica Kmer, Tndia, Africa, Cingapura, Filipinas, Birmânia, Brunei, Papua, Nova Guiné e outros Países da América Latina

(**) A Malásia foi responsāvel por $45 \%$ do total da produção mundial.

Fonte: SUDHEVEA (4). 
seguido por uma sensivel estagnação, em cujo contexto a coleta do cacau representava uma das poucas atividades comerciais de vulto. Sua baixissima densidade demogräfica, aliada $\bar{a} s \underline{x}$ tremas dificuldades de transportes, tornavam a Amazônia uma região de modestos recursos econômicos. Mesmo a atividade ca caueira, como o fora anteriormente - sob dominio jesuistico a exploração das "drogas do sertão", era predominantemente ex trativa, com precārios resultados econômicos.

Foi neste contexto que, $j \bar{a}$ no início do século XIX, começou a se desenvolver, atravēs da cidade de Belēm, um pequeno comércio exportador de artefatos de borracha lcal çados, "seringas", etc... I. Mas, foi somente a partir da segunda metade do século que a atividade goméfera adquiriu alguma significação para a região":

Este ambiente sōcio-econômico é relatado por PINTO (17). 0 mesmo autor diz que os primeiros passos para se efetivar a exploração gomífera foram dados em 1852 com a aprovação dos Estratutos da Companhia de Navegação do Amazonas, dirigida por Mauá, que iria permitir a navegação a vapor nas águas do Amazonas e Pará, pois um dos entraves à exploração da borracha na região amazônica era a falta de acesso às regiões produtoras.

Superado o problema de transportes na região, desencadeou-se o processo de especialização da economia amazô nica, com uma crescente produção de borracha, como pode ser visto na Tabela 22 . 
Tabela 22 - Produção de Borracha na Amazônia - $1827 / 1890$.

\begin{tabular}{cc}
\hline Ano & Tonelada \\
\hline 1827 & 31,36 \\
1830 & 156,06 \\
1837 & 283,92 \\
1840 & 388,26 \\
1845 & 561,46 \\
1850 & $1.466,55$ \\
1860 & $2.673,00$ \\
1870 & $6.591,00$ \\
1880 & $8.679,00$ \\
1890 & $16.394,00$ \\
\hline
\end{tabular}

Fonte: REIS, Arthur C.F. (21) citado por PINTO (17).

No início do século $x x$, a borracha tornara-se uma matêria-prima imprescindível às economias industrializa das, transformando o controle de seu suprimento em elemento de peso na dispura politico-econômica que se avizinhava.

Dessa forma, é possivel vislumbrar dois períodos nesse movimento de corrida às regiões produtoras de borra cha vegetal. o primeiro, que se estendeu até o início do pre sente século, foi dominado pelos interesses ingleses, secundados pelos holandeses e franceses, e teve seu ponto culminan te na transferéncia do eixo produtor de borracha da Amazônia 
para o Sudeste Asiático. 0 segundo, que se prolongou atè o presente momento, teve - sob impulso alemão, soviético e norte-americano - como caracteristica principal, a crescente subs tituição da borracha vegetal pela sintētica.

Neste ültimo movimento, o episōdio decisivo foi, sem düvida, o esforço de guerra norte-americano, entre 1939 e 1945

A nivel da indústria de artefatos de borracha, esses dois periodos corresponderam ao declínio "relativo" do setor produtor de artigos de vestuário e mecánico em geral, em proveito da crescente preponderáncia do setor de material de transporte, como pneus e cāmaras de ar.

Voltando ao que foi dito quanto a corrida às regiões produtoras de borracha végetal, observou-se que os se tores econômicos envolvidos na indūstria de artefatos dos paí ses europeus começaram a manifestar crescente interesse pelas atividades produtoras da matéria-prima.

Em 1850 Thomaz Hancock advoga o plantio sistemático de espécies produtoras de borracha nos dominios britânicos. Segundo CARDOSO (9), em $1867,70 \mathrm{mil}$ sementes de seringueira foram levadas do Brasil para Kew, Inglaterra, por H. Wickhann, das quais 2 mil germinaram. Posteriormente, foram recambiadas para Sri-Lanka (ex-Ceilão), Cingapura e Malásia onde se adaptaram admiravelmente. Foi esse o ponto de partida das plantações que se estabeleceram na Ásia.

A expansão do cultivo da seringueira no Sudes- 
te Asiático, na primeira década do século xx, contou com grandes inversões inglesas na região, alēm do apoio de uma infraestrutura agrícola já implantada e de conhecimentos técnicos bastante desenvolvidos.

Ainda, de acordo com CARDOSO (9), o desvelo pe la nova cultura foi tamanho que já no ano de 1900 a Ásia aparecia nas estatísticas com uma produção de 500 toneladas, quan tidade equivalente a $1 \%$ do consumo mundial. Nesse mesmo ano, - Brasil produziu 18 mil e 800 toneladas participando com $35 \%$ do consumo. Dez anos depois, em 1911, a Asia produziu 18 mil toneladas enquanto que o Brasil participou com $36 \mathrm{mil}$ toneladas: De ano para ano, a produção asiática continuou crescendo e, quarenta e cinco anos após a ida das sementes de hevea para o oriente, terminava a supremacia do Brasil na produção de borracha.

A Tabela 21, já citada, mostra a posição dos principais paises produtores de borracha, inclusive do Brasil, no período de 1972/81.

o Brasil, que até 1910 colocou-se em primeiro lugar como produtor de borracha vegetal tem hoje uma participação em torno de $1 \%$. A produção nacional, que tem crescido nos ültimos 15 anos, está aquém das suas necessidades, deixan do o país em situação de dependência dos produtores asiáticos para suprir a demanda interna. Analisando os dados apresenta dos na Tabela 23, observa-se que a produção brasileira de bor racha natural em 1985 atingiu 42 mil toneladas enquanto o con 
Tabela 23 - Evolução da Produção e do Consumo de Borrachas Na turais no Brasil, Décadas de $50 / 60$ e $61 / 70$ e no Período $1971 / 85$ (em 1.000 t/peso seco).

\begin{tabular}{|c|c|c|}
\hline Período & Produção & Consumo \\
\hline $1950 / 60$ & 64,0 & 108,5 \\
\hline $1961 / 70$ & 195,6 & 268,2 \\
\hline 1971 & 24,3 & 41,8 \\
\hline 1972 & 25,8 & 44,2 \\
\hline 1973 & 23,4 & 51,2 \\
\hline 1974 & 18,6 & 57,9 \\
\hline 1975 & 19,3 & 58,7 \\
\hline 1976 & 20,3 & 66,1 \\
\hline 1977 & 22,6 & 71,4 \\
\hline 1978 & 23,7 & 72,5 \\
\hline 1979 & 25,0 & 75,9 \\
\hline 1980 & 27,8 & 81,1 \\
\hline 1981 & 30,3 & 74,4 \\
\hline 1982 & 32,8 & 67,8 \\
\hline 1983 & 35,2 & 70,2 \\
\hline 1984 & 36,0 & 88,7 \\
\hline 1985 & 42,0 & 102,0 \\
\hline
\end{tabular}

Fonte: NEVES, Evaristo M. (14) e SUDHEVEA (7). 
sumo foi de $102 \mathrm{mil}$ toneladas, situação bastante crítica numa época em que o país enfrenta sērias restriçōes na área de importação a fim de melhorar o perfil da balança de pagamen tos. A situação torna-se mais grave quando se sabe que $80 \%$ da produção interna provém de seringais nativos, em estado de extrativismo. De acordo com PINTO (17), enquanto no sudeste Asiático procura-se melhorar os transportes, a assistência mé dica, a produção de alimentos, a pesquisa agronômica, a imigração e as condições de trabalho, na região amazônica o excedente gerado pela atividade extrativista era, em sua quase totalidade, desviado para outras regiões e grande parte dos recursos empregados na região concentrava-se no setor de serviços, tendo-se descuidado intei ramente do aperfeiçoamento das atividades produtivas.

Alguns observadores mais lúcidos há muito que vinham se manifestando a favor de profundas transformações na estrutura produtiva das regiōes mais tradicionais. Algumas iniciativas governamentais, embora timidas, de cunho politico-econômico, foram postas no papel. A maioria ficou apenas no papel e algumas poucas que foram implantadas não tiveram sucesso.

Na realidade, a tardia consciência de que a economia gomífera amazônica estava à beira do colapso resultou num crescente clamor pela intervenção e amparo governamen tais. Reivindicava-se uma imediata "injeção" de recursos financeiros, sob a forma de um programa de valorização da borra cha. Alēm disso, nunca é demais lembrar que, por mais que a 
indústria de elastómeros sintéticos esteja, a cada ano, cres cendo mais aceleradamente do que o crescimento da borracha na tural (Tabelas 19 e 24) é ainda bastante remota a possibilida de de a borracha sintética vir a substituir integralmente a natural; para a maioria dos produtos industriais, cuja princi pal matēria-prima é a borracha, um percentual de borracha natural na produção è ainda indispensāvel. E claro que esse percentual varia de um produto para outro, como pneus de aero naves, nos quais a borracha natural tem uma faixa absolutamen te dominante.

A partir do encarecimento do petróleo e da nova conjuntura política do Sudeste Asiático, o investimento na heveicultura brasileira passou a ser visto como uma oportuna reserva estratégica. Em 1972 foi lançado o primeiro "Programa de Incentivo à Produção da Borracha Natural" - PROBOR 1 Instituido pelo Decreto no 1.232, de $17 / 07 / 1972$.

Para a consecução desse programa foram destinạ dos recursos no montante de 320 milhões de cruzeiros, a fim de atender as necessidades de crédito e assistência técnica.

Esse programa, que inicialmente previa a implantação de $20 \mathrm{mil}$ hectares de seringais (posteriormente fixou-se em $18 \mathrm{mil}$ ), a recuperação de $5 \mathrm{mil}$ hectares de seringais de cultivo e a recuperação de $10 \mathrm{mil}$ "colocações" (seringais nativos), atingiu um indice de $77 \%$ das metas previstas. Dos $18 \mathrm{mil}$ hectares, inicialmente previstos, existem 13 mil e 782 hectares de seringais de cultivo implantados em con 
Tabela 24 - Evolução da Produção e do Consumo de Borrachas Sin téticas no Brasil, Período 1963/83 (em 1.000 tone ladas).

Ano Produção ${ }^{1}$ Consumo ${ }^{1}$

\begin{tabular}{lrr}
\hline 1963 & 30,0 & 34,4 \\
1964 & 32,5 & 50,0 \\
1965 & 38,9 & 37,9 \\
1966 & 54,2 & 51,4 \\
1967 & 51,5 & 57,0 \\
1968 & 58,9 & 70,5 \\
1969 & 61,7 & 71,2 \\
1970 & 75,5 & 85,4 \\
1971 & 78,2 & 97,5 \\
1972 & 94,6 & 114,3 \\
1973 & 125,6 & 149,5 \\
1974 & 155,2 & 166,2 \\
1975 & 128,8 & 176,3 \\
1976 & 164,4 & 201,6 \\
1977 & 188,1 & 204,7 \\
1978 & 206,1 & 222,0 \\
1979 & 223,8 & 225,5 \\
1980 & 249,1 & 243,8 \\
1981 & 222,9 & 201,3 \\
1982 & 228,1 & 194,6 \\
1983 & 220,9 & 199,2 \\
$1984^{2}$ & - & - \\
$1985^{2}$ & - & - \\
\hline 1 & &
\end{tabular}

Inclui polibutadieno (derivada do álcool) e SBR (sintético es 2 tirenobutadieno, derivada do petróleol.

Sem dados oficiais

Fonte: NEVES, Evaristo M. (14) e SUDHEVEA (5). 
dições normais. Diz a SUDHEVEA (6) que, na realidade, foram plantados com recursos do PROBOR 1, 21 mil e 358 hectares dos quais 7 mil e 576 hectares foram, por diversos motivos (abandono, incêndio, inadimplência, etc), considerados irrecuperá veis e, conseqüentemente, deixaram de ser contabilizados nas estatisticas.

De acordo com PINTO (17), a anälise do PROBOR 1 podeser feita em dois níveis. 0 primeiro diz respeito aos programas de recuperação de seringais nativos, instalação de usinas de beneficiamento de borracha e recuperação de seringais de cultivo, cujos resultados dever-se-iam fazer sentir em prazo relativamente curto (trēs ou quatro anos). 0 segundo nivel relaciona-se com os programas de longo prazo, tais como, a formação de seringais de cultivo e o de assistência técnica e formação de pessoal, que deveriam começar a apresen tar resultados após oito anos quando do início das primeiras produções, tornando, portanto, prematuras quaisquer anāi ises a respeito do seu sucesso, por ocasião da implantação do programa. Mas, no tocante às medidas de curto prazo, é possível observar alguns de seus resultados.

O PROBOR I previa, a partir dos subprogramas de recuperação de seringaís nativos e de cultivo, uma evolução da produção nacional de borracha vegetal, como é visto na Tabela 25 .

Comparando os dados desta tabela com os apresentados na Tabela 23, a disparidade é flagrante. Previa-se 
um aumento da ordem de $80 \%$ no periodo $1973 / 80$ mas, na realida de, o aumento foi de $18 \%$. As explicações para tal realidade são diversas.

Tabela 25 - Produção Programada de Borracha Vegetal, Período $1973 / 80$.

\begin{tabular}{ll}
\hline Ano & Toneladas \\
\hline 1973 & 28.000 \\
1974 & 31.000 \\
1975 & 37.000 \\
1976 & 37.000 \\
1977 & 38.000 \\
1978 & 40.000 \\
1979 & 45.000 \\
1980 & 51.000 \\
\hline
\end{tabular}

Fonte: PINTO, Nelson P.A. (17), P.154.

E provāvel que boa parte dos recursos recebidos pelos mutuários daquele programa tenha sido utilizada em outros empreendimentos e, se assim foi, o comportamento da produção parece ter acompanhado a evolução dos preços relatí vos da borracha vegetal ao invés de responder ao programa de reabertura de seringais de cultivo.

Segundo PINTO (17), o relatório de avaliação do PROBOR I na Amazónia, elaborado em setembro de 1975, quan 
do fala do Subprograma de Instalação de Usinas de Beneficiamen to na Amazónia, observa o seguinte: - "A instalação de 9 us nas de beneficiamento na Amazónia pode ser considerada como um fracasso, uma vez que, apenas uma foi contratada e mesmo assim no ültimo ano do Programa, quando esta e outras deveriam estar funcionando". 0 mesmo relatörio diz que o insuces so deste Subprograma foi um dos responsáveis pela queda de pro dução da borracha natural.

Entre as causas do fracasso são apontadas a falta de material botânico para o enxerto de mudas, a ausência de mão-de-obra e de técnicos especializados, a ocorrência de pragas e molëstias e, principalmente, a mä aplicação do di nheiro do PROBOR I pelos executores dos projetos beneficiados. Em 03/10/1977, atravēs dá Resolução CNB 33/77, - Conselho Nacional da Borracha instituiu o "Segundo Programa de Incentivo à Produção de Borracha Natural" - PROBOR II (20) com o objetivo de implantar $120 \mathrm{mil}$ hectares de seringueiras, recuperar 10 mil hectares de seringais de cultivo e recuperar $15 \mathrm{mil}$ "colocações", alēm de financiar viveiristas, visando a envolver a iniciativa privada no processo de formação de mudas, o que era, anteriormente, de responsabilidade ex clusiva da SUDHEVEA, alēm de alguns subprogramas.

Os beneficios deste segundo programa, com vigência para o período $1977 / 82$, foram estendidos ao Estado do Espirito Santo, além das tradicionais äreas de cultivo: Amazônia Legal e Litoral Sul da Bahia. 
Para este segundo programa, foram destinados cerca de quatro bilhões e duzentos milhões de cruzeiros.

o PROBOR II, que previa a implantação de 120 mil hectares de seringais de cultivo no periodo 1978/82, contava em dezembro de $1983 \mathrm{com}$ pouco mais de $74 \mathrm{mil}$ hectares. Quanto à recuperação de seringais de cultivo, cuja meta estabelecia recuperação de $10 \mathrm{mil}$ hectares, na mesma data, o quadro era o seguinte: recuperados completamente 1 mil e 600 hec tares e, em fase final de recuperação, cerca de $3 \mathrm{mil}$ e 400 hectares, conforme SUDHEVEA (6).

Uma vez constatada a impossibilidade de se atingir as metas propostas dentro do prazo estabelecido e dada a crescente necessidade de expandir a produção, o prazo de vigência do PROBOR 11 foi antecipado para 1981 , possibil tando a instituição do terceiro programa - PROBOR 111 , assina do em 23/04/82 e com vigência para o período 1982/94. Uma das metas do terceiro programa era implantar, até 1987, mais 250 mil hectares de seringais de cultivo que, juntamente com as àreas plantadas através dos programas anteriores, deveriam proporcionar ao Brasil a auto-suficiência em borracha natural até o final da década de 80 , com estimativas de um excedente exportável de $148 \mathrm{mil}$ toneladas a partir de 1985.

A possibilidade de se incrementar a produção de borracha natural atravēs da conquista de novas fronteiras agrícolas, permitiu que se incluísse no PROBOR III, àreas não tradicionais na heveicultura mas com aptidão ecológica para o 
seu desenvolvimento como, por exemplo, os Estados do Mato Gros so do Sul, Goiás e São Paulo, além de territōrios da Amazônia Legal, Bahia e Espírito Santo. Estas três ültimas regiões tí veram prioridade na programação, tanto em termos de àrea financiada como em relação às taxas de juros para financiamento destinados à formação de seringais de cultivo, diferenciadas para as áreas de atuação da SUDAM/SUDENE e demais regiões.

Entretanto, CASTRO et alii (10) e BORREANI et ali i (3), citados por NEVES (14) mostraram, através de estudos sobre projeções de produção e consumo de borracha natural até o ano 2.000 , que o Brasil não conseguirá a auto-suficiência interna tão propalada quando da implantação dos três programas.

Para que tais previsões se concretizem, afirmam os autores que seriam necessários investimentos adicionais. A SUDHEVEA (6), diz que não foi possivel consolidar a me ta prevista para os anos 1982 e 1983 , pois além de o PROBOR 111 trazer em seu bojo inovaçōes como as miniusinas, consti tuindo substanciais alterações em sua estrutura se comparado com os programas anteriores, O PROBOR 111 contou ainda com sé rias restrições orçamentärias, além de alterações nos mecanismos de financiamento e modificações das taxas de encargos financeiros. 


\section{APENDICE 2}

\section{CARACTERIZACÃO DAS REGIÕES E SISTEMAS DE PRODUCÃO}

Vale do Ribeira

- Caracterizagão Física 1

A região situa-se ao sul do Estado de São Pau1o, compreendida entre os paralelos 47 e 49 ; limita-se ao sul e sudoeste com o Estado do Paraná; a leste com o oceano At lân tico e a oeste e noroeste com a Serra de Paranapiacaba. A Iimitação ao nordeste é feita com municípios em processo de tran sição, quase que característicamente turísticos. Por sua pro ximidade com a Serra, apresenta oscilações de temperatura com a mínima de $6,8: \mathrm{C}$ e a máxima de $38,8: \mathrm{C}$.

Quanto ao tipo de solos, a região caracterizase por solos hidromórficos e podzólicos vermelho e amarelo,

I Fonte: SÃo PAULO, Secretaria da Economia e Planejamento (23). 
ocupando mais de $50 \%$ da ärea, propícios à agricultura. Entretanto; segundo levantamentos realizados por vārios órgãos da Secretaria da Agricultura sobre a capacidade de uso dos solos do litoral, verificou-se que o mesmo apresenta $84 \%$ de sua área em solos de relevo e $16 \%$ em solos de baixada com proble mas de drenagem. o levantamento aerofotogramétrico, realizado pelo IAC, em 1962, mostra que a região litorânea (1itoral centro e sul) ocupa uma ārea de 1.383 .900 hectares, dos quais $2,5 \%$ era ocupado pela bananicultura. Em razão da alta porcen tagem de solos não mecanizäveis e em razão das condições climáticas tropicais, nenhuma das culturas do planalto paulista teve condições de fixar-se no litoral.

\section{- A Heveicultura no Vale do Ribeira}

Dentro dessas características, pesquisadores do IAC, hä mais de vinte anos, jà alertavam as autoridades competentes no sentido de se dar prioridade ao desenvolvimento de culturas que se ajustassem à capacidade dos solos do litoral de São Paulo, isto é, culturas de características florestais, identificando, entre elas, a cultura da seringueira, pois já dispunham de experimentos que comprovaram a sua adaptabilidade na região com rendimentos económicos capazes de promover o desenvolvimento regional.

Os primeiros experimentos datam de 1952, quando o IAC conseguiu as primeiras sementes que foram trazidas da Libēria, de plantações da Companhia Firestone. 
Os dados obtidos mostraram claramente, a adaptą ção da seringueira às diferentes condições ecológicas das localidades objeto dos primeiros estudos. Contudo, quanto. à produtividade das plantas, os resultados revelaram certa deficiência, uma vez que, a heterogeneidade do material de plan tio não permitia algo melhor. No entanto, o comportamento nas plantações de indivíduos com alta capacidade de produção revelava as reais possibilidades dessas regiões para a heveicultura.

Ao mesmo tempo em que se procedia à importação de sementes da Libéria, o IAC providenciava a introdução, em São Paulo, de material clonal de alta produção existente em örgãos oficiais do Brasil e örgãos de pesquisa do exterior. Essa iniciativa permitiu, alēm da obtenção de novos dados de produtividade, a formação de seringais com alguma diversifícação de clones, dentro.de sua população.

Quanto à qualidade da borracha produzida diz CARDOSO (9) que, testes efetuados pelo Instituto de Pesquisas Tecnolōgicas de São Paulo (IPT), mostraram que a borracha aqui produzida apresentou qualidades superiores de tração e resistência ao envelhecimento acelerado de seus vulcanizados, quan do comparado ao típo "Fina Acre", utilizada como padrão.

Com base nos resultados obtidos nos experimentos realizados pelo IAC na região litorânea, concluiu-se que a região apresenta razoáveis possibilidades para o desenvolvi mento da heveicultura, em que pesa a possibilidade da presen- 
ça, em carāter endēmico, do Microcyclus ulei. Na opinião dos pesquisadores, è no litoral sul do Estado, representado pelo Vale do Ribeira, que empreendimentos heveícolas apresentam melhores possibilidades de sucesso.

Entretanto, as evidências parecem mostrar que não será ainda a. curto e médio prazos que os örgãos governamen tais de pesquisa conseguirão sensibilizar as autoridades no sentido de investir no Vale a fim de tirä-lo do estado de sub desenvolvimento. Apesar do esforço do Governo do Estado de investir em estradas, energia, educação e saúde, esses fatores, por si só, não provocaram o desenvolvimento econômico re gional.

$$
\text { A respeito do Vale do Ribeira, CARDOSO }
$$

transcreve um trecho de um estudo realizado pela faculdade de Filosofia, Ciências e Letras da Universidade de São Paulo.

"A região do Vale do Ribeira se encontra claramente partilhada em duas zonas fisiogrāficas: uma zona litorânea e uma zona montanhosa. Na primeira delas, integram-se os municipios de Peruibe, Mongaguā, Itanhaém, Iguape, Cananēia, Mira catu, Pedro de Toledo, Juquiā, Pariquera-Açū, Registro e Eldorado. Na segunda zona, integram-se os municipios de Apiat, Ribeira, Tapiraî, Iporanga, Ribeiräo Branco, Barra do Turvo, Sete Barras e Juquitiba. 
A unidade dessas duas zonas esta na sua pouca densidade demogrāfica e em seu atraso econômico. Devido ao fenômeno das enchentes $e$ porcentagem de florestas e terras desmatadas $e$ abandonadas, a região é conhecida como Amazônia Paulista.

- Vale do Ribeira, como ārea equivalen te a $10 \%$ da superficie total do Estado de São paulo, tem nivel muito baixo de aproveitamento de terras, $j \bar{a}$ que apenas $7 \% \bar{e}$ utilizada em atividades agropecuārias. Em comparação com o resto do Estado, pode-se dizer que é inexplorada. A pequena atividade agricola, baseada nas culturas de banana, milho, chā, tomate, batata-inglesa $e$ arroz, totaliza apenas $2,8 \%$ da produção estadual. As indüstrias de transformação regionais representam $0,19 \%$ da transformação industrial do Estado de São Paulo. Dos principais produtos da Lavoura, a banana, que representa 55\% da produção regional, mantêm-se estāvel, com pequenos desvios anuais. Jā o arroz, milho e beijão, que representam 1,4\% da produção agrícola, vêm apresentando quantidades decrescentes, com baixo ren dimento por ārea.

Em ritmo crescente estão o chã, o tomate e a batata-inglesa, com rendimentos por ārea 
relativamente bons, indicando que se trata de cul turas provavelmente trabalhadas de maneira mais moderna que nas atrās enumeradas.

No que diz respeito ao crescimento populacional, a região do Vale do Ribeira também se encontra em inferioridade quando comparada a outras regiões do Estado de São Paulo. Enquanto a população deste cresce a um ritmo de mais ou menos 3,6\% ao ano, a do vale do Ribeira não vai além de 1,4\%. Por outro lado, enquanto o. Estado apresenta uma densidade demogräfica de 52,3 habitantes por quilômetro quadrado, o vale não apresenta mais do que 9,5 habitantes por quilômetro qua drado.

No que toca à composição da população, o setor urbano reūne $27 \%$ dela e o setor rural, $73 \%$. Para o Estado de são paulo as porcentagens são aproximadamente $41 \%$ de habitantes na zona urbana e 59\% de habitantes na zona rural. Percebe-se as sim que o vale do Ribeira se caracteriza como uma zona, predominantemente rural, dentro de um estado que tende cada vez mais a possuir maior quanti dade de população urbana".

Embora tal descrição conste de um trabalho ela borado em 1966, pode-se afirmar que as alterações havidas nos 
últimos anos não afetaram, significativamente, o quadro sócio-econômico da região, possibilitando inclusive que CARDoso (9) concluisse o seguinte:

- Demograficamente, a região do Vale do Ribeira se caracteriza como um estágio ainda primitivo de ocupação do território, taxa de urbanização muito baixa e ritmo de cres cimento muito lento;

- Economicamente, predomina o setor primärio, sendo inexistente o secundário. o setor primärio, por sua vez, caracteriza-se por niveis muito baixos de aproveitamen to das terras jā que só $7 \%$ são utilizadas.

- Os municípios da região trazem uma contribuição económica muito pequena à formação da renda estadual.

o autor conclui alertando da necessidade de uma tomada de decisão a fim de que essa região, que apresenta área de 25 mil quilometros quadrados, possa ter um desenvolvimento compativel com o progresso de São Paulo, sugerindo, como uma boa opção para o setor agrícola, a atividade heveícola.

o otimismo e entusiasmo de técnicos e pesquisa dores envolvidos nos programas de pesquisa com a hevea no Vale do Ribeira foram responsáveis pelo interesse despertado em alguns produtores da região em adquirir mudas para o plantio em propriedades particulares, no início da década de 60.

os seringais remanescentes dessa época contam hoje com mais de vinte anos de idade e o interesse na sua exploração deu-se após a primeira crise do petróleo, em 1973. 
Com os preços da borracha em alta, a demanda por mudas passou a aumentar, atingindo, em 1985, 566.645 plan tas, distribuidas entre 135 produtores de 13 municipios, como mostra a Tabela 3 .

os plantios foram realizados com recursos pröprios, dada a inexistência de programas especiais de crédito destinados à heveicultura no Vale do Ribeira. Neste ponto, são necessärios alguns esclarecimentos a respeito. Por ocasião da instituição do PROBOR III, que incluiu o Estado de São Paulo no seu programa de ação, o Vale do Ribeira foi excluído dos benefícios do programa porque os técnicos da SUDHE VEA consideraram que a região era suscetível ao "Mal-das-FoIhas". Entretanto, apōs algum tempo, em 1984, o Superintendente da SUDHEVEA realizou uma visita à região acompanhado por técnicos e pesquisadores de São Paulo, convencendo-se de que a região oferecia condições propícias ao plantio da seringuei ra. Dessa visita resultou um convēnio entre SUDHEVEA e Federação da Agricultura do Estado de São Paulo (FAESP) que estipulava que o organismo federal subsidiaria as mudas existentes no Vale, mais precisamente, mudas formadas por viveirista particular credenciado pela Secretaria da Agricultura e Abastecimento. Esse acordo estabelecia que as mudas seriam vendidas a preço de custo, preferencialmente, a pequenos produtores e num mäximo de 2 mil unidades. Infelizmente, foram poucos os produtores beneficiados com esse programa, pois tal convênio teve curta duração. 
A maioria dos agricultores que optou pela adoção da heveicultura, fê-lo na expectativa de retornos que a hevea poderá proporcionar a longo prazo, realizando o plantio em äreas impróprias para as demais culturas, geralmente em morros, pois, dada a escassez de terrenos planos, estes são destinados, preferencialmente, às culturas de ciclo curto, principalmente produtos alimentares.

Nas unidades agrícolas pesquisadas, a seringueira convive com culturas que são exploradas comercialmente, como: banana, chá, arroz, maracujá, produtos hortícolas, pecuäria bubalina e plantas ornamentais.

Em geral, o proprietärio e sua família risidem na propriedade, participando e supervisionando todas as ativi dades. As propriedades que possuem atividades mais diversif cadas contam com alguma mão-de-obra contratada temporariamente.

Neste quadro, a cultura da seringueira recebe cuidados especiais apenas no primeiro ano, por ocasião do plan tio. Mesmo assim, os indices de perda chegam a atingir até $20 \%$.

o sistema de produção mais usual na região é o plantio de mudas com raiz nua, adquiridas de viveiristas da prōpria região mas, há produtores que jā estão formando mudas em viveiros pröprios.

Os coeficientes técnicos por operação e as exí gências físicas de insumos, por hectare, referentes ao prime ro sistema de produção citado, são mostrados na Tabela 26. 
Tabela 26 - Coeficientes Técnicos e Preços de Fatores de Produção (Maio de 1985), para os Periodos de for mação e Manutenção da Cultura da Seringueira, 1 ha, 400 Plantas, Sistema de Produção por Aquí sição de Muda Enxertada e Plantio com Raiz nua, Produtividade Média ha/ano: 2.000 $l$ látex, Vá le do Ribeira, Estado de São Paulo.

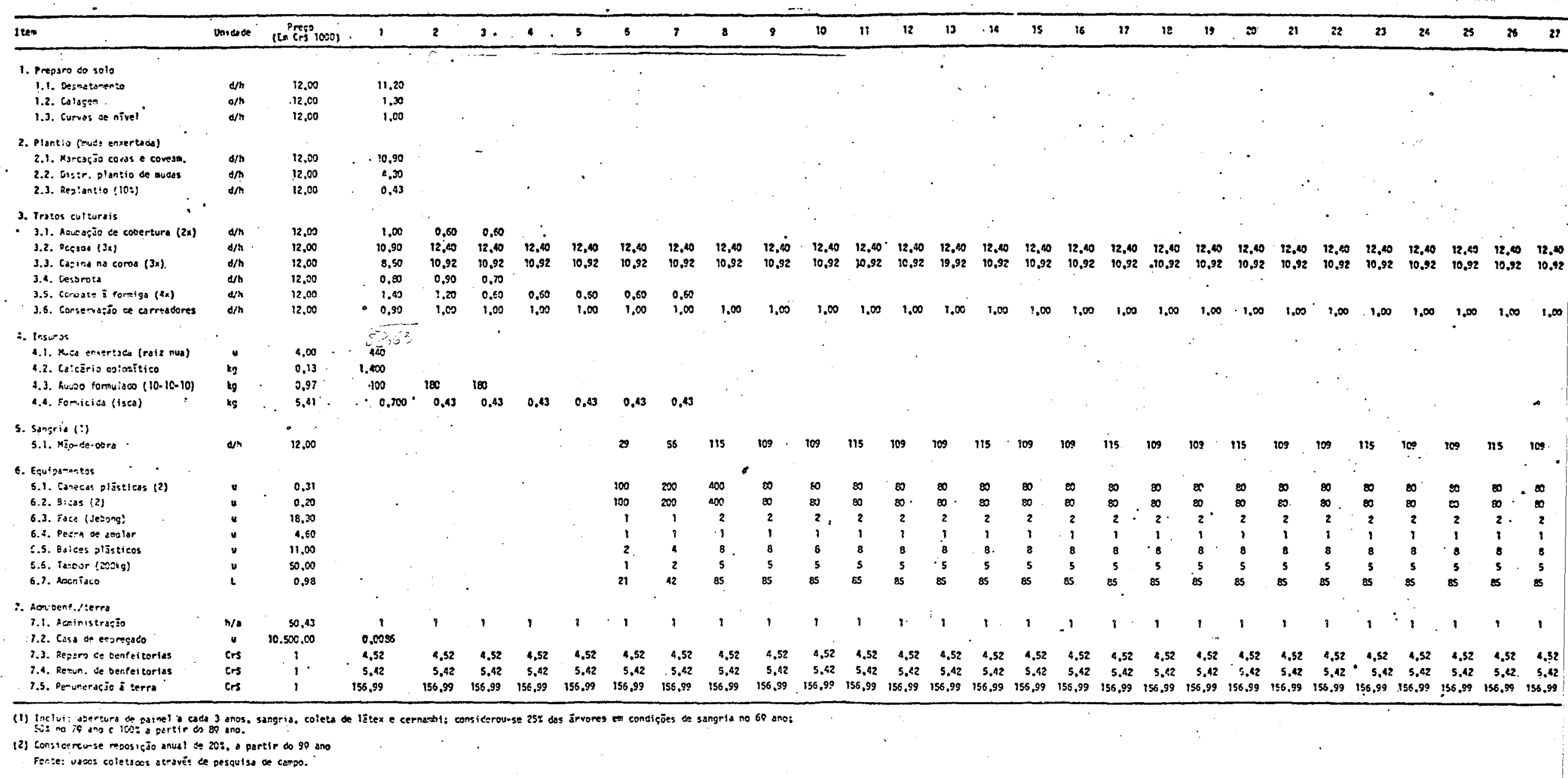


As operações que constam da matriz são as prạ ticadas com maior frequéncia pelos agricultores e os coefici entes técnicos e exigências de insumos representam a média, ponderada pela área total da amostra.

o fato de a seringueira ser plantada em terreno acidentado, não permitindo o uso de maquinarias, faz com que o cultivo seja realizado manualmente. Tratando-se de cul tura perene, as exigências em termos de mão-de-obra são mais intensas no primeiro ano, principalmente para as operações de desmatamento e plantio de mudas; do total de 52,63 dias de serviço, as operações mencionadas requerem 22,10 dias, ou seja, aproximadamente $40 \%$ do total.

Do segundo ao quinto ano, o nümero de dias de serviço necessários para a condução de l hectare representas a cada ano, cerca de $20 \%$ das exigências requeridas no primeiro ano, pois as operações restringem-se, apenas, aos tratos cul turais, como capinas e combate à formiga.

Em termos de adubação, obtervou-se uma preocupação por parte dos agricultores em limitar, na medida do possível, os. gastos com fertilizantes - a adubação, quando realizada, è feita no māximo atē o terceiro ano - uma vez que os plantios, como já foi observado, são realizados com recursos pröprios. Tratamento fitossanitärio, tambëm não é uma prá tica usada, a não ser quando o produtor constata algum indício de doença. Nesses casos, recorre aos serviços prestados pelo Instituto Biológico. 
Quanto aos insumos usados no periodo de formação, restringem-se à mudas, calcārio, adubo formulado e formi cida.

A partir do início da produção, sexto ano, a cultura jä passa a requerer maior utilização de mão-de-obra. Considerando-se que no sexto ano $25 \%$ das ärvores já se encontram em condições de sangria, tem-se uma exigência de 54 dias de serviço, por ha/ano; no sétimo ano, o nümero de plantas che gà a 50\%, e a exigência é de 80 dias, por ha/ano; no oitavo, $100 \%$ das ärvores (considerando-se 400 plantas por hectare) jā estão em plena produção, requerendo cerca de 140 dias de serviço, considerando as operações de sangria e tratos cul turais. Analisando os coeficientes da Tabela 26 , observa-se que o nümero de dias de serviço, na sangria varia a cada dois anos. Essa variação é devida ầ abertura de painēis que, em geral, é feita a cada très anos.

Na fase de exploração, os equipamentos usados são os exigidos para a sangria, como canecas plàsticas, bicas, facas (jebong), pedras de amolar, baldes plästicos, tambores e amoníaco (utilizado para evitar a coagulação do látex).

Para canecas e bicas, considerou-se uma reposi ção anual de $20 \%$ a partir do terceiro ano de exploração ou oitavo de plantio.

Outro sistema de produção que começa a ser adọ tado pelos produtores do Vale do Ribeira é a formação de mudas enxertadas em viveiros prōprios. 0 s dados referentes a 
este sistema são mostrados na Tabela 27 , ondé contam as operações realizadas, os coeficientes tēcnicos referentes às exi gências com mão-de-obra e maquinarias e os insumos usados para o plantio de 1 hectare.

Os critēriós utilizados na apuração destes dados foram os mesmos do sistema de produção comentado anterior mente.

A principal distinção entre um sistema e outro diz respeito, unicamente, à fase de implantação que, nes te caso, inclui o preparo do germinador e do viveiro de mudas. A partir do segundo ano não há distinção entre os sistẹ mas, pois as operações realizadas restringem-se a tratos culturais, comuns em ambos os sistemas. No sistema anterior, cons tatou-se, na fase de implantação, que as exigências em termos de dias de serviço somavam 52,63 dias de mão-de-obra comum, aproximadamente, a metade das exigencias quando o produtor opta por formar a prōpria muda, pois só o preparo de germina dor e das mudas requer cerca de 40 dias de serviço de um trabalhador, alēm da utilização de máquinas em algumas operações. Nesta fase, as operações mais exigentes em mão-de-obra, são a do corte do porta-enxerto e arranquio das mudas.

No Vale, os porta-enxertos, em geral, são plan tados diretamente no solo e transplantados quando já estão com cerca de doze meses de idade. Neste caso, a operação de arranquio requer certo cuidado, sendo realizada com lentidão. 0 corte do porta-enxerto e o arranquio foram englobados numa úni 
Tabela 27 - Coeficientes Técnicos e Preços de Fatores de Produção (Maio de 1985), para os Periodos de For mação e Manutenção da Cultura da Seringueira, I ha, 400 Plantas, Sistema de Produção de Formá ção de Muda Enxertada em Viveiros Próprios, Produtividade Média ha/ano: 2.000 l de lätex, Vale do Ribeira, Estado de São Paulo.

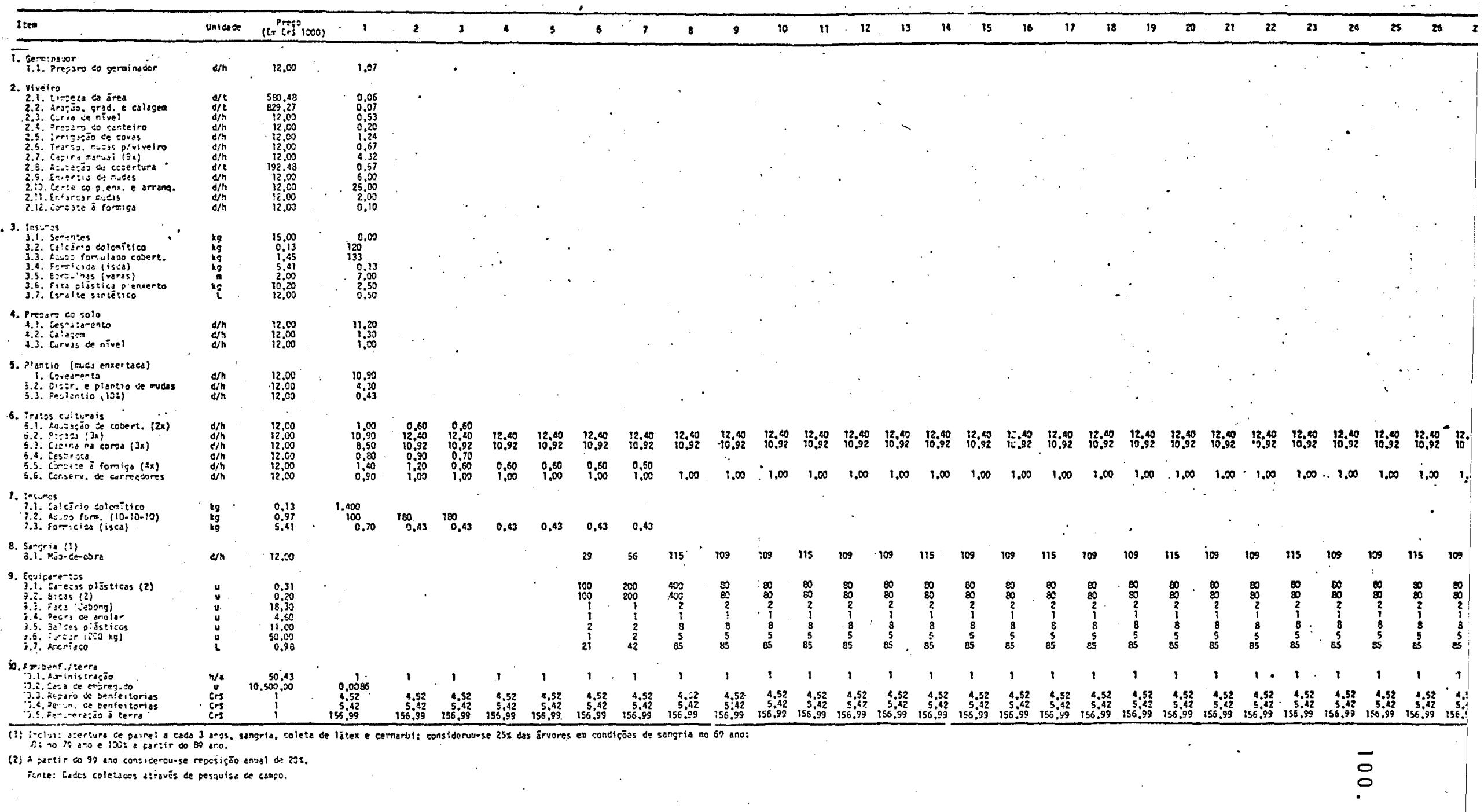


ca operação, devido à dificuldade de os entrevistados fornecerem.os dados separadamente. Sobre o corte do porta-enxerto, cabe uma explicação quanto ao uso de antitranspirante utiliza do após o corte: os produtores do Vale usam tinta a óleo, enquanto no planalto o porta-enxerto é protegido com plástico.

Com referência aos insumos e equipamentos utilizados, com exceção daqueles usados no preparo das mudas, os demais são os mesmos usados no sistema de produção já comenta dos anteriormente.

As borbulhas para enxertia são adquiridas de jardins clonais da prōpria região ou de produtores do planalto.

Além dos coeficientes técnicos para cada operação e das exigências físicas de insumos apuram-se, também, dados sobre a produtividade média, por ha/ano. $0 s$ dados reve laram que a produção média dos seringais adultos do vale do Ribeira situa-se ao redor de 2.000 litros de látex por ha/ano, com sangrias em dias alternados e um total de 250 dias trabalhados.

A produtividade dos seringais do Vale é inferior a dos seringais do planalto e, de acordo com explicações fornecidas por pesquisadores do IAC, a produtividade mais ba xa deve-se ao fato de que no Vale há necessidade de diversifi car os clones, a fim de evitar a ocorrência da doença "Maldas-Folhas". Desse modo, recomenda-se clones mais resistentes à doença, porém, com menor produtividade e clones de alta produção. 
102.

Como jà foi dito, esses seringais estão com idade média de 25 anos e não receberam quaisquer tratos cultü rais na fase de formação. Contudo, com os novos clones existentes, muitos deles originários da Malásia, e com um acervo maior de pesquisas sobre a hevea, è de se esperar que os novos seringais atinjam produtividades superiores às que hoje. são obtidas.

SÃo José do Rio PrETO

- Caracterizagão física ${ }^{2}$

A Região de São José do Rio Preto integra, jun tamente com as regiōes de Araçatuba e Presidente Prudente, a porção extremo oeste do "p.lanalto Ocidental". Elas guardam, - de modo geral, grande homogeneidade paisagistica, salvo as saliências da Serra do Diabo no "Pontal Paulista" e repartem, entre si, os extremos "chapadões rebaixados", entre os quais ocorrem os tributários do Rio Paraná.

A grande homogeneidade estrutural e geológica empresta ao relevo regional uma aparência monótona, com exten sos chapadões de vertentes convexas suaves. Estes chapadões,

2 Fonte: SÅO PAULO, Secretaria de Economia e Planejamento (24).

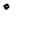


em seus niveis mais baixos, apresentam colinas rasas, terraços e planicies aluviais.

A amplitude topogräfica para toda a extensão da região gira por volta dos $500 \mathrm{~m}$ incluindo as faixas hisométricas que vão de 200 a $700 \mathrm{~m}$, e distribuindo o terreno entre as seguintes proporções de tipos de topografia:

$\begin{array}{lr}\text { Topografia ondulada } & 77,46 \% \\ \text { Topografia plana } & 19,22 \% \\ \text { Topografia montanhosa } & 3,32 \%\end{array}$

Do ponto de vista topográfico, a região não apresenta empecilhos à motomecanização das lavouras.

A distribuição das chuvas, em totais anuais, confere aos $48,71 \%$ da àréa da região, uma precipitação da ordem de $1.200-225 \mathrm{~mm}$ ao longo do eixo maior de divisores de àguas, enquanto que, nas porções periféricas, registram-se as faixas de:

$1.250-225 \mathrm{~mm}$ para a porf̧ão nodeste cobrindo os $41,51 \%$ da regiãọ.

$1.150-225 \mathrm{~mm}$.nas vertentes correspondentes aos vales dos Rios São José dos Dourados e Tietê.

$1.100-225 \mathrm{~mm}$ restritos às proximidades da calha do Tietê.

outro indicador para o regime pluviométrico in teressado ao melhor aproveitamento agrícola das terras, é o 
nümero médio de dias com chuvas, que podem ser visualizados através da Tabela 28 em duas localidades da região.

Quanto aos tipos de solo, devido ao predomínio dos arenitos de Bauru, a maioria dos solos da região possui características arenosas, apresentando limitações quanto à fertilidade.

os principais grupos de solos que ocorrem na Região de São José do Rio Preto são:

Podzolizados de Lins e Marília - V. Lins $(32,80 \%)$;

Podzolizados de Lins e Marília - V. Marília $(22,79 \%)$

Latossolo roxo- $(11,18 \%)$;

Latosolo vermelho escuro fase arenosa $(28,68 \%)$.

Embora a regiäo tenha sofrido um devastamento desenfreado de sua cobertura vegetal, deixando como consequén cia solos desgastados, nada impede, face às condições climäti cas regionais, que práticas conservacionistas, uso de adubos e corretivos adequados, uso racional do solo e motomecanização controlada, possam reabilitar as terras visando ao aumento da produtividade agropastoril.

\section{- A Heveicultura na Região}

Ao mesmo tempo em que se procedia aos plantios de seringais no litoral paulista, área inicialmente escolhida 
Tabela 28. Número Médio de Dias de Chuva, por Mês, em Duas Localidades da Região de São Josē do Rio Preto, Estado de São Paulo.

\begin{tabular}{llllllllllllllll}
\hline Localidade & jan & fev & mar & abr & mai & jun & jul & ago & set & out & nov & dez \\
\hline Onda Verde & 16,4 & 14,2 & 12,2 & 4,9 & 3,0 & 2,2 & 2,2 & 1,5 & 3,3 & 9,2 & 12,8 & 13,1 \\
Pindorama & 13,7 & 12,2 & 9,5 & 4,1 & 2,3 & 3,7 & 1,7 & 1,2 & 3,5 & 7,7 & 10,3 & 11,8 \\
\hline
\end{tabular}

Fonte: SCHRODER, R. Distribuição e Curso Anual das Precipitações no Estado de São Paulo Zona VIII, In : São Paulo, Secretaria de Economia e Planejamento (24). 
por apresentar parâmetros ecológicos pröximos aos observados nas regiões de origem da seringueira, era tentada a implantaçäo dessa cultura no planalto paulista. A existência de exem plares com ótimo desenvolvimento em algumas zonas do planal to, ensejava um futuro promissor para a heveicultura. Do mútuo trabalho do serviço de Expansão da Seringueira e do IAC, quer na troca de material clonal, quer na discussão de proble mas inerentes à implantação da nova cultura, surgiram os pri meiros seringais racionais em terras do planalto paulista. Des ses seringais pioneiros é que se obtiveram os resultados präticos de que hoje lançam. mão aqueles que lidam com a seringuei ra para apregoar e.reivindicar um programa heveícola para são Paulo.

Dos primeiros plantios realizados na região, final da década de 50 e início de 60, sobreviveram em franca produção, cerca de $62 \mathrm{mi} .1$ e 500 plantas. Esses seringais, co mo diz CARDOSO (9), permitiram o estudo fenológico da cultura e, como resultado prático, tem-se hoje 2.520 .638 plantas, con forme dados da Tabela 3 .

Algumas dezenas de milhares de ärvores, cujo plantio ocorreu no final da década de 70 , jā se encontram pro duzindo, com resultados que ultrapassam a expectativa dos téc nicos e pesquisadores.

Apōs a tabulação dos dados referentes às propriedades entrevistadas, observou-se que não havia um sistema de produção homogêneo na região. Isto, devido à escassez de 
técnicos especialistas no assunto e à falta de conhecimento por parte dos produtores, por tratar-se de uma cultura sem tradição no Estado. Entretanto, para efeito de anälise, foram selecionados três sistemas.

o primeiro, mais usual, refere-se à formação de porta-enxerto em viveiro próprio e enxertia no campo, isto é, após o plantio dos "cavalos" em local definitivo. As operações realizadas, as exigências de mão-de-obra e maquinārias, os insumos e equipamentos requeridos, para a formação de 1 hectare, com mēdia de 400 àrvores, são mostrados na Tabela 29.

o segundo sistema è o mais utilizado pelos gran des produtores: a muda é formada e enxertada em viveiros próprios, utilizando-se borbulhas de jardins clonais tamberm formados na própria propriedade. 0 s dados referentes a este sís. tema são mostrados na Tabela 30 .

o terceiro modo de produção é mais usual em propriedades que não dispõem de inframestrutura para formar um viveiro. Infra-estrutura, neste caso, significa local apropriado e mão-de-obra. Nesses casos, os produtores adquirem as mudas enxertadas, que podem estar acondicio nadas em sacos plästicos ou balaios ou, então, em raiz nua. Es te sistema está representado na Tabela 31 .

Como se observa nas referidas tabelas, as operações usadas, os coeficientes tēcnicos de fatores de produção, os insumos e equipamentos, são mostrados para todo o horizonte temporal e cobrem desde o preparo do germinador (no 
Tabela 29 - Coeficientes Técnicos e Preços dos Fatores de Produção (Maio de 1985), para os Períodos de For mação e Manutenção da Cultura da Seringueira, 1 ha, 400 Plantas, Sistema de Produção por Forma ção de Porta-Enxerto e Enxertia de Campo, Produtividade Média ha/ano: 2.800 \& lätex. Região de São José do Rio Preto, Estado de São Paulo.

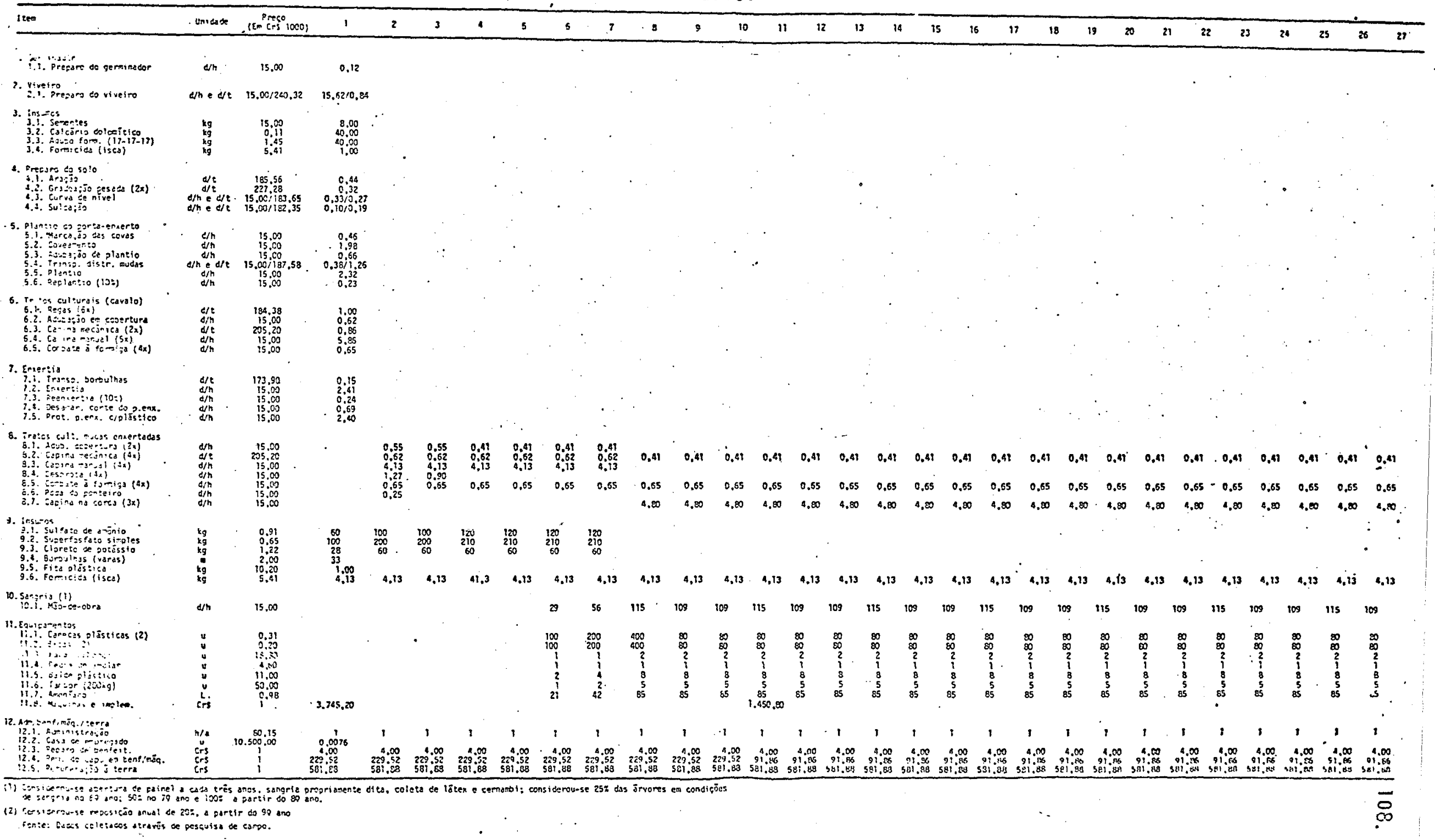


Tabela 30 - Coeficientes Técnicos e Preços de Fatores de Produção (maio de 1985), para os Periodos de Formação e Manutenção da Cultura da Seringueira, 1 ha, 400 Plantas, Sistema de Produção por Formação de Mudas Énxertadas em Viveiro Próprio, Produtividade Média ha/ano: $2.800 \ell^{\text {de }}$ látex, Re giăo de São José do Rio Preto, Estado de São Paulo.

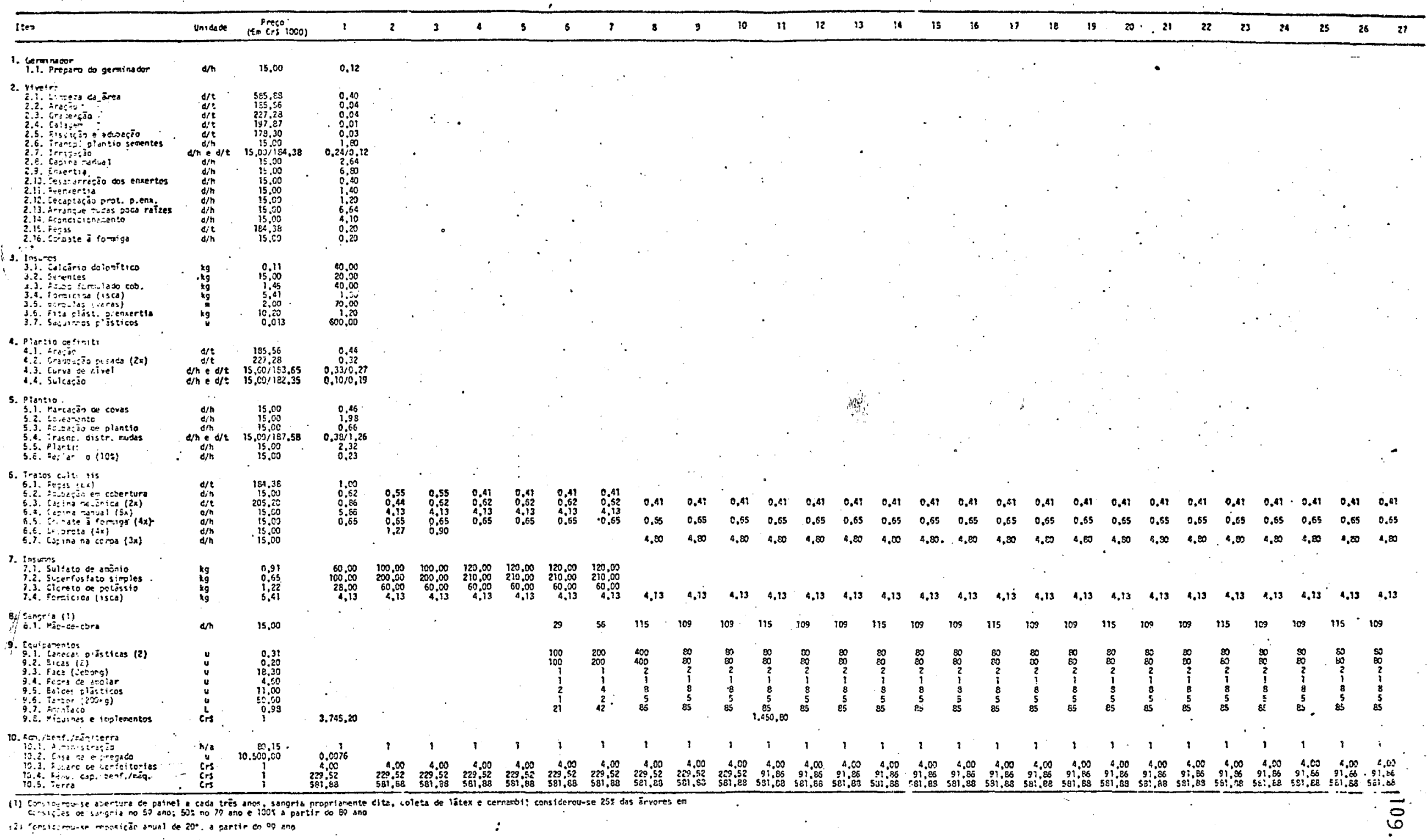


Tabela 31 - Coeficientes Técnicos e Preços de Fatores de Produção (Maio de 1985), para os Períodos de Formação e Manutenção da Cultura da Seringueira, I ha, 400 Plantas, Sistema de Produção por Aquisição de Muda Enxertada, Produtividade Média ha/ano: 2.800 l de lätex, Região de São josé do f Rio Preto, Estado de São Paulo.

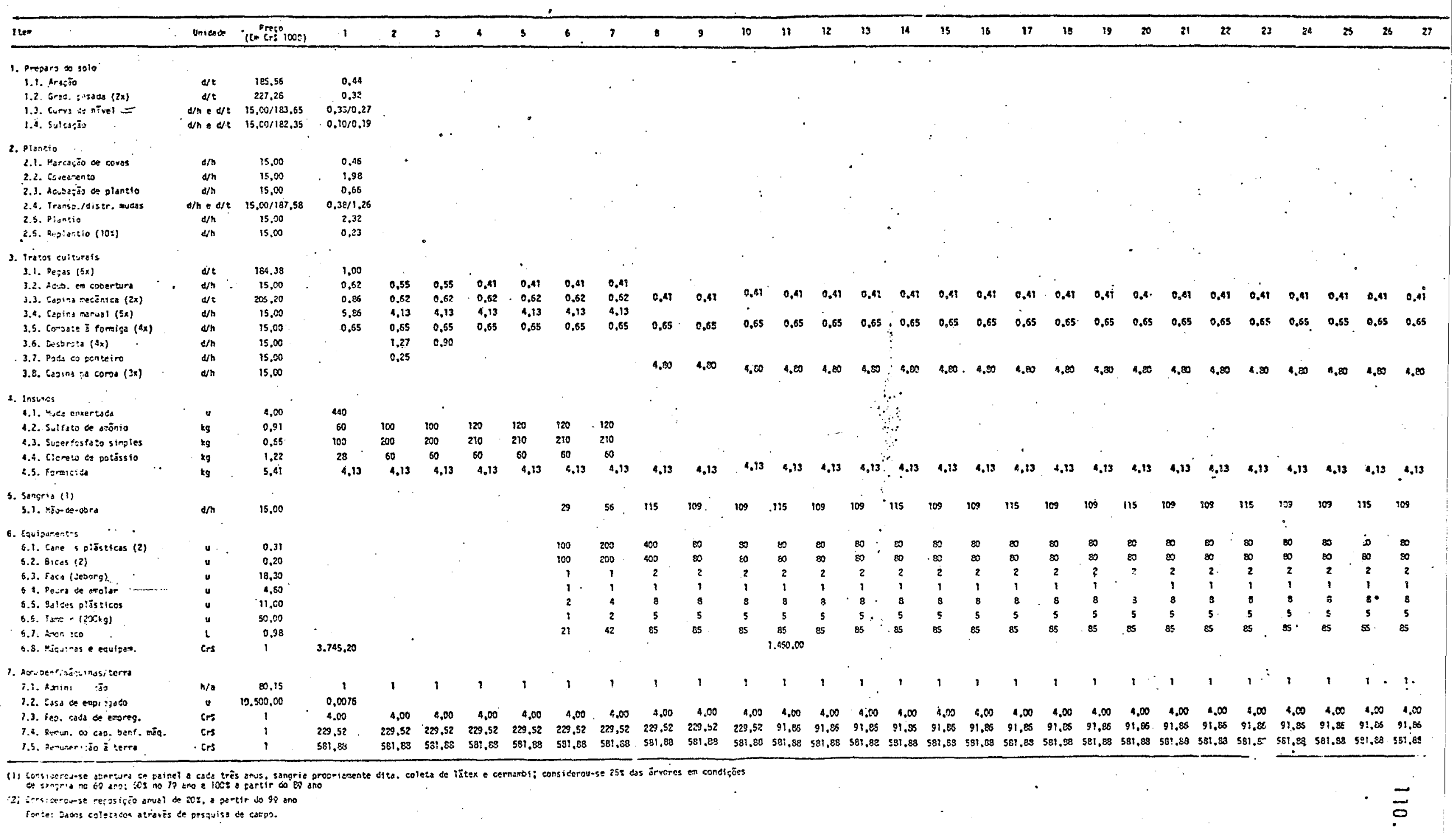


caso de formação de porta-enxerto e muda) até a sangria, alēm de incluir as remuneraçöes à administração, capital investido em benfeitorias e máquinas e remuneração à terra.

As diferenças entre um sistema de produção e outro baseiam-se, quase que exclusivamente, nas exigências de dias de serviço de mão-de-obra comum e no uso de maquinarias, no primeiro ano de investimento.

0 primeiro sistema exige um total de 40,4 dias de serviço, dos quais $13 \%$ refere-se a dias de serviço de trator.

Desse mesmo total, $41 \%$ dos dias de serviço säo destinados ao preparo do germinador e do viveiro, na formaçäo de porta-enxertos. 0 restante, refere-se às exigências requeridas para o plantio no local definitivo e nos tratos cul turais.

Dentre as operações realizadas após o plantio, a mais exigente, em termos de mão-de-obra, é a capina manual, operação que è realizada, em mëdia, cinco vezes ao ano, seguindo-se as operações de enxertia e proteção do porta-enxerto que, como já foi mencionado por ocasião dos comentärios so bre os seringais do Vale do Ribeira, é feita com saquinhos plás ticos a fim de evitar a evaporação da seiva. Esta proteção é posteriormente retirada.

0 segundo sistema, por ser mais "sofisticado", exige maior utilização de mão-de-obra, principalmente, no pre paro do germinador e na formação das mudas, pois, neste caso, 
as mudas (porta-enxerto) são enxertadas no próprio viveiro e transplantadas para o campo. Este sistema requer um número maior de operações na fase da formação da muda e, consequlente mente, mais mão-de-obra.

Para um total de 44,31 dias de serviço, no pri meiro ano, somente o germinador e o viveiro exigem $65 \%$ dos dias de servif̧o, tanto de mão-de-obra comum como de tratorista. O uso de trator, tanto neste sistema como no anterior, restringe-se, praticamente, às operações de preparo do solo; a fase de tratos culturais requer um uso restrito de trator, praticamente só na operação de capina mecânica.

o terceiro sistema é o menos exigente em dias de mão-de-obra, pois as mudas são adquiridas jā enxertadas. As operações, neste caso, são as realizadas no campo: preparo de solo, plantio e tratos culturais.

Em termos de insumos, os dois primeiros sistemas de produção são os mais exigentes, pois, além dos insumos usados no viveiro, hä os fertilizantes usados após o plantio definitivo.

Em qualquer dos casos, a adubação é feita, em média, até o sexto ou sétimo ano. No presente trabalho, foi considerada adubação até o sētimo ano, com base em trabalhos de pesquisa e informações de tëcnicos e pesquisadores.

Na fase adulta do seringal, do oitavo ano em diante, os tratos culturais restringem-se às capinas e ao com bate à formiga. Nesta fase, as operaçöes concentram-se na san gria. 
Com o objetivo de simplificar as matrizes considerou-se, na operação de sangria, a abertura de painéis (reạ lizada a cada trés anos), a sangria propriamente dita, a cole ta do lätex e do cernambi.

A sangria ém cada ärvore é realizada em meia espiral e em dias alternados, sistema $\frac{S}{2} ; \frac{d}{2}$ mas, hä produtores que estão usando estimulante para aumentar a produção, porēm, neste caso, a recomendação é de que a sangria deve ser feita a cada três ou, mesmo, a cada sete dias.

o responsável pelo seringal, dedica-se a ele durante cinco horas do dia, aproximadamente. A operação inicia-se logo ao clarear do dia e se estende até às 9 ou 10 horas; no perído da tarde é feita a coleta do lätex e do cernambi .

Dado que a sangria ē uma operação bastante delicada, pois requer muita firmeza e precisão no corte, o san grador é poupado de trabalhos que exigem grande esforço físico, dedicando-se a tarefas leves no restante do dia.

- Os dados referentes à produtividade foram obtidos de 32.000 ärvores, acusando a mëdia de 2.8001 itros de látex por hectare/ano, ou seja, $30 \%$ a mais da produtividade do Vale do Ribeira:

Tal diferença estä associada às variedades clo nais usadas numa região e outra, pois enquanto os seringais do Vale do Ribeira estão sujeitos ao Microcyclus ulei os do planalto dificilmente correm esse risco. 
Por ocasião da pesquisa de campo e mesmo nos dias atuais, toda a produção de borracha do Estado de São Pau 10 é comercializada na forma do lätex in natura, pois os produtores ainda não dispõem de usinas para processamento da bor racha bruta. Contudo, futuramente, a tendência é partir para a comercialização de folhas fumadas, pois jä existe no Estado tecnologia para a montagem de miniusinas nas propriedades. A vantagem consiste em obter um produto final com melhores características técnicas e melhor aceitação no mercado, além de facilitar o transporte e o armazenamento. A usina de processamento apresenta, como vantagem adicional, um aumento no lucro do produtor, pois, de acordo com BERNARDES et ali i (2), os preços estipulados pelo Conselho Nacional da Borracha (CNB) e que são homologados pelo Conselho Interministerial de Preços (CIP) para os värios tipos de borracha seca, são mais com pensadores do que o preço pago para o látex in natura. 